Article

\title{
Heavy Rainfall Events and Mass Movements in the Funchal Area (Madeira, Portugal): Spatial Analysis and Susceptibility Assessment
}

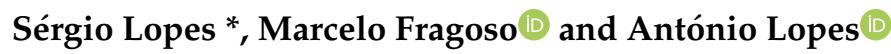 \\ Institute of Geography and Spatial Planning, University of Lisbon. Rua Branca Edmée Marques, Cidade \\ Universitária, 1600-276 Lisboa, Portugal; mfragoso@campus.ul.pt (M.F.); antonio.lopes@campus.ul.pt (A.L.) \\ * Correspondence: lopes.sergiodasilva@gmail.com
}

Received: 14 November 2019; Accepted: 4 December 2019; Published: 15 January 2020

check for updates

\begin{abstract}
The article presents new information on the spatial distribution of intense rainfall and a new map of susceptibility to the formation of mass movements in the mountainous streams of the municipality of Funchal, the capital of the Autonomous Region of Madeira, an archipelago of Portugal. The methodology that was adopted is based on the spatial analysis of weighted overlap of variables, with influence in the occurrence of hydro-geomorphological processes that are at the origin of catastrophic events, marked by the mobilization of solid material towards and along the fluvial channels. Intense precipitations are effectively the main triggering factor of mass movements, which is why their statistical characteristics and local contrasts are analyzed, to integrate this layer of information into the new susceptibility assessment model of mass movements produced in this article. This type of spatialized information is of strategic importance to support the planning of urban expansion, which requires a land use management practice in accordance with the existing risk in the Madeira Island.
\end{abstract}

Keywords: Funchal; mountain streams; mass movements; susceptibility; multi-criteria analysis

\section{Introduction}

In general, most scientific studies of natural risks analysis have focused on hazard analysis, namely, the study of the characteristics of the phenomena [1,2], which is indeed a fundamental diagnostic phase to the subsequent risk management process. However, the issue of spatial incidence is not always adequately addressed, therefore, depending on the quality of the available thematic cartographic information sources, with this research work, we intend to contribute to the deepening of knowledge on the spatial distribution of mass movements, that can cause damage as a result of solid material movement.

The most studied natural hazard in mountain places are snow avalanches, slope movements, and floods in alluvial plain environments. The literature about the flows associated with transport of debris by mountain torrents is scarcer. Several phenomena like debris flows, mudflows, or woody debris are synergistically controlled by conditioning factors (e.g., availability of sediments in the upper sectors of the basins, steepness of the slopes, the longitudinal profile of the streamlines) and triggering factors, generally, the occurrence of intense precipitation. A streamflow which gains intensity following a heavy rainfall event can be classified according to the solid flood discharge present at any given time on a given stream reach. It is usual to distinguish three stages: normal stream flow in which the solid fraction is less than $40 \%$; hyper-concentrated streamflow in which the solid fraction varies from 40 to $60 \%$; debris flow with more than $60 \%$ solids $[3,4]$. However, in nature, the conditions of flow and of solid concentration may occur on a continuous basis, evolving at different phases and in different sectors of the basins. 
The formation of turbulent flows in the mountain streamlines that run towards the main watercourses is the worst natural risk that threatens the city of Funchal. This phenomenon, locally called "alluvium", is a mixture of hydro-geomorphological complex processes that differ from a strictly hydrological flood, due to the high amount of rocky and organic material in circulation. A mixture of varied debris, from particles to large rocky blocks and tree trunks, adds to the water flow and these dynamics can be associated with the so-called torrent processes. Similar occurrences have been described in mountainous areas, such as the Austrian Alps [5], Southern Italy [6,7], and France [8].

The methods that can be considered in the analysis of susceptibility to mass movements and flood zones can be used independently or combined and can generally be classified into three types: (a) historical method [9,10]; (b) hydrological and hydraulic models [11-15]; (c) empirical methods based on multi-criteria analysis [16-19]. The application of combined methods can include, for example, an integrated analysis of hydro-geomorphological processes based on field observations, on the interpretation of aerial photography and of satellite-derived data, on historical documentation analysis [20,21], and on numerical modeling of debris flow [22]. Regarding the multi-criteria analysis, the estimation of areas prone to mass movements occurrence results from the integration and weighting of information of the various explanatory factors of the phenomenon studied $[17,18]$. Other alternative methodological approaches are based on the technique of producing scenarios (Formative Scenario Analysis) that are indicative of patterns and trajectories of flow and its probabilistic structure [23,24].

Regarding the spatial patterns of precipitation, the identification of areas of greatest susceptibility to intense rainfall is an irrefutably important information source for the evaluation of mass movements. A better knowledge of precipitation variation, through the production of prediction schemes of its space-time distribution, can represent a significant progress in the definition of warning systems and extreme hydro-geomorphological events alert systems [25]. Nevertheless, the spatial modelling of this variable depends, to a large extent, on the quality and availability of data series of surface observations [14].

The space-time variability of rainfall is particularly important in strongly urbanized basins sectors, which is why recent studies have drawn attention to this issue [26-29]. In urban areas, the hydrological processes are characterized by strong temporal and spatial variability and tend to respond quickly to small-scale temporal and spatial variations of rainfall [14].

After the great storm of February 2010 [20] there was an increase of scientific publications focusing the study of intense rainfall in Madeira Island. Some aimed to characterize its spatial distribution patterns [12,25], others focused on meteorological aspects of that rain event, in particular [15,20,30,31]. The geomorphological dynamic phenomena and processes triggered by the 20 February, 2010 storm were also investigated and inventory maps of the landslides were drawn up [32]; this has enabled scientists to estimate the volume of solid material produced during this particular event, which ranged from $217,000 \mathrm{~m}^{3}$ to $344,000 \mathrm{~m}^{3}$ in the three main river basins of Funchal.

From the perspective of a strict management of natural risks, it is essential to bear in mind that phenomena of this nature are characterized by the chaotic behavior of flows, by high stream velocity, and by the difficulty in forecasting their spatial incidence. These aspects strongly condition the effectiveness of early warning systems and limit the actions of emergency response [13,25]. Therefore, the effectiveness of an early warning system for hydro-geomorphological extreme events depends, to a large extent, on the capacity and quality of monitoring and forecasting the precipitation [33-36]. However, monitoring is not an end by itself, but the goal is to increase the knowledge about the behavior and local variation of extreme events.

The limitations explained above emphasize the importance of identifying the areas of the territory under greater risk in order to put in place appropriate measures of mitigation. After the succession of debris flow and flash flood events in 1993, 2001, 2007, 2009, 2010, 2012, and 2013 on Madeira Island, the current risk management process should not neglect the concept of cross-multidisciplinary and integrated approach, capable of linking structural and non-structural measures and to improve the constructive capacity, the regional planning, and the resilience of the community to address the disaster. 
In this sense, the analysis of susceptibility and the delimitation of protection and risk zones are essential, in accordance with the guidelines issued by the Directive 2007/60/EC of the European Parliament and of the Council on the assessment and management of flood risks, in an integrated management model of the territory.

\subsection{Goals}

The present work aims to achieve two goals: firstly, to identify the parts of the territory more prone to the occurrence of intense rainfall; secondly, to produce a mass movement susceptibility map for the small mountain basins of the municipality of Funchal. The information about the areas likely to be affected by mass movements is important for spatial planning and in the planning and preparation phase, for the civil protection action.

\subsection{Study Area}

Funchal is a municipality with an area of $76.15 \mathrm{~km}^{2}$, located on the southern side of Madeira, a mountainous island with $740.7 \mathrm{~km}^{2}$ in the eastern subtropical area of the North Atlantic Ocean (Figure 1). This paper focuses on the analysis of the susceptibility only in a part of the territory, but this methodological proposal can be applied to the whole other part of the island, given the common biophysical characteristics of the hydrographic basins.

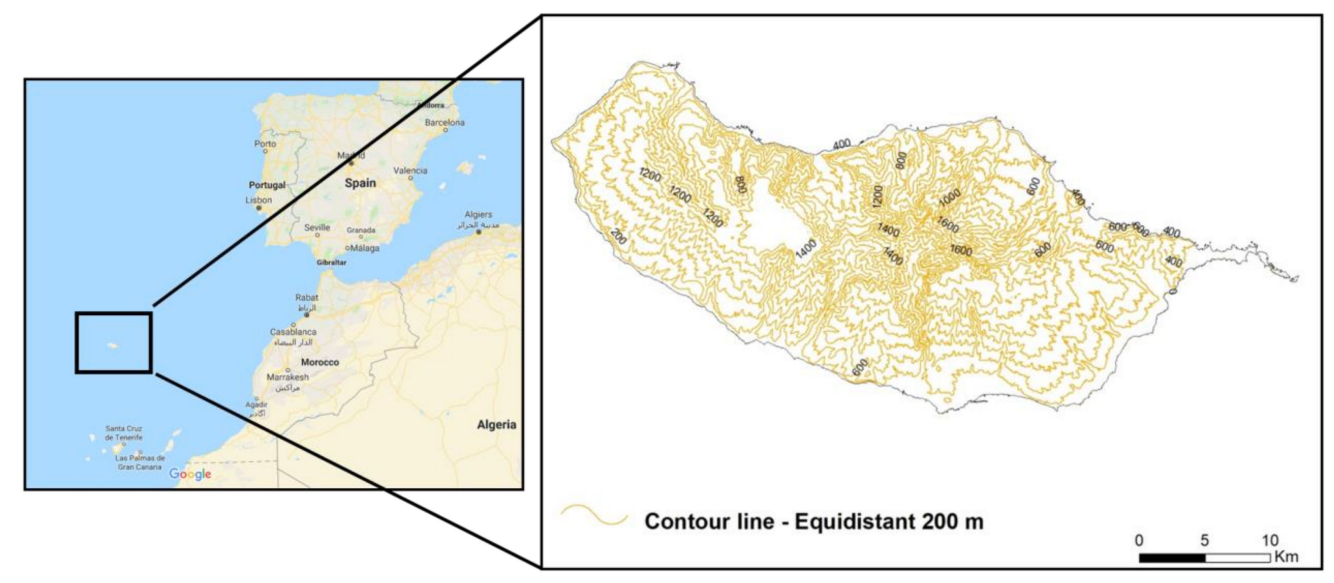

(a)

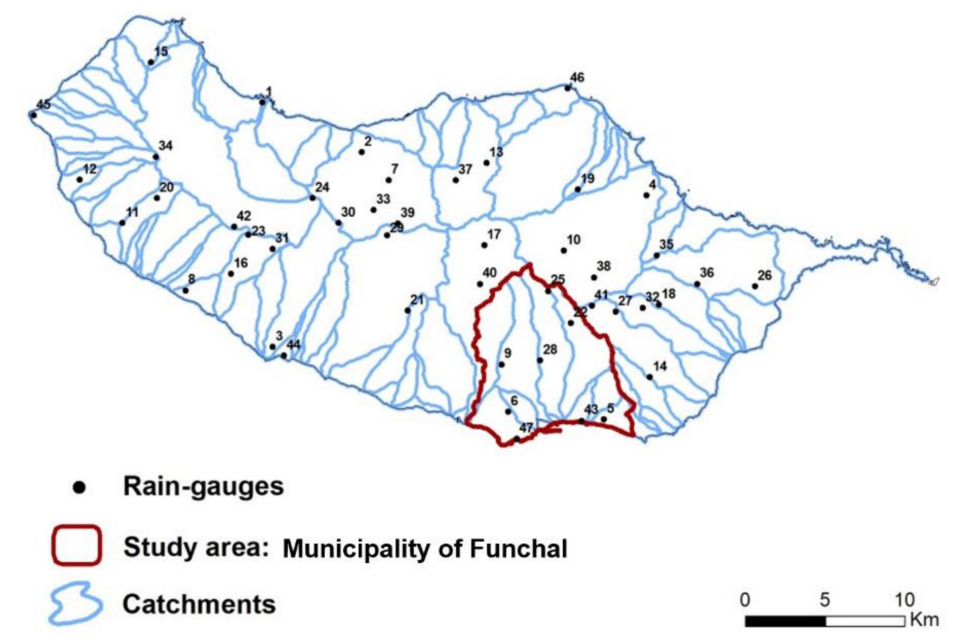

(b)

Figure 1. Location and relief (a) of the island of Madeira (Portugal), and (b) location of the 47 rain-gauges considered in this study. 
The "amphitheatre" topographic form of the study area may be responsible for the confluence at the lower troposphere levels, of the flows from South/Southwest, making this sector of the island more prone to upward air flows, that occasionally result in the occurrence of intense and short-term precipitation events and consequently in mass movements and flash floods. The city is partially located in the terminal sector of alluvial deposition of three main streamlines, whose headwaters rise above $1500 \mathrm{~m}$ altitude. The corresponding basins cover approximately more than half $(58 \%)$ of the total area of the municipality. The drainage basins factors are vital to explain the high level of hydro-geomorphological hazard, namely the irregular relief and the deep incision of narrow valleys, the small size of the elongated stream basins $\left(13 / 14 \mathrm{~km}^{2}\right)$, the short main watercourses $(10 / 11 \mathrm{~km})$ and low concentration-time $(<2 \mathrm{~h})$. The significant urbanization of the basins, with the urban perimeter traced around 600,700 , and $800 \mathrm{~m}$ of altitude has resulted in excessive impervious surfaces and in increased overland flow, which is itself another factor that tends to contribute to the aggravated flood magnitude and extension of the affected area. Most of the municipal area is mountainous, including the coastal shoreline which has high cliffs in almost of its extent. There are about 128 mountain torrents in the three main basins of Funchal, whose area of their hydrographic subsystems is $62 \%$ of the total area.

\section{Data and Methods}

The precipitation data and digital cartography used in this work was made available by the competent authorities: Portuguese Institute for Sea and Atmosphere (IPMA) and Regional Laboratory of Civil Engineering. In this section of the paper, the methodologies and procedures followed to obtain the results of susceptibility model are further explained.

\subsection{Description of Data}

Regarding precipitation, the density of pluviometric stations (PS) on the island of Madeira $\left(1 \mathrm{PS} / 16 \mathrm{~km}^{2}\right)$ is in general quite satisfactory as it approaches the average density recommended [37] for the analysis of its spatial variation in mountainous areas $\left(1 \mathrm{PS} / 15 \mathrm{~km}^{2}\right)$. The network of PS provides continuous precipitation recording (udometer with digital recording system) that allows the statistical analysis of the variation of the rain for sub-daily periods and presents a relatively dense cover. However, the series available are still short spanning, less than a decade.

The analysis of the precipitation was carried out based on the PS data, whose location is shown in Figure 1 and its general description is in Table 1 . Table 2 provides detailed information on the temporal and spatial framework of the data considered in the various analyses. Different temporal intervals of climatic series and different groups of PS were considered in the statistical analysis and in the spatial representation of the values of precipitation, depending on the purpose of the analysis and on the available data. More precisely, to elaborate the regional maps of the intense precipitations presented in Figure 6A,B, all PS listed in the Table 1 were used, whereas for statistical treatment purposes, only the set of PS located in the study area (Funchal) were considered.

Table 1. Description of the network of pluviometric stations (PS) considered in this work.

\begin{tabular}{|c|c|c|}
\hline Code & Designation & Altitude (m) \\
\hline 1 & Seixal & 70 \\
\hline 2 & S. Vicente & 120 \\
\hline 3 & Ponta do Sol & 130 \\
\hline 4 & Lombo dos Palheiros & 212 \\
\hline 5 & São Gonçalo & 220 \\
\hline 6 & São Martinho & 260 \\
\hline
\end{tabular}


Table 1. Cont.

\begin{tabular}{|c|c|c|}
\hline Code & Designation & Altitude (m) \\
\hline 7 & Achada do Til & 300 \\
\hline 8 & Massapez & 300 \\
\hline 9 & Trapiche & 590 \\
\hline 10 & Fajã Nogueira & 629 \\
\hline 11 & Prazeres & 632 \\
\hline 12 & Fajã Ovelha & 635 \\
\hline 13 & Fajã do Penedo & 637 \\
\hline 14 & Camacha & 675 \\
\hline 15 & Santa do Porto Moniz & 675 \\
\hline 16 & Pinheiro Fora & 750 \\
\hline 17 & Curral das Freiras & 800 \\
\hline 18 & Casa Velha & 880 \\
\hline 19 & Pico das Pedras & 920 \\
\hline 20 & Pico Verde & 1020 \\
\hline 21 & Trompica & 1188 \\
\hline 22 & Parque Ecológico do Funchal & 1300 \\
\hline 23 & Pico da Urze & 1365 \\
\hline 24 & Estanquinhos & 1590 \\
\hline 25 & Areeiro & 1590 \\
\hline 26 & Machico & 170 \\
\hline 27 & Meia Serra & 1100 \\
\hline 28 & ETA Alegria & 611 \\
\hline 29 & Encumeada & 854 \\
\hline 30 & Bica da Cana & 1585 \\
\hline 31 & Cova Grande & 1340 \\
\hline 32 & Ovil & 1014 \\
\hline 33 & Fajã Rodrigues & 575 \\
\hline 34 & Fonte do Bispo & 1245 \\
\hline 35 & Santo Serra, Lamaceiros & 784 \\
\hline 36 & Santo da Serra, Quinta & 660 \\
\hline 37 & Achada da Madeira & 521 \\
\hline 38 & Chão das Feiteiras & 1180 \\
\hline 39 & Chão dos Louros & 900 \\
\hline 40 & Curral das Freiras ETA & 743 \\
\hline 41 & Poiso, PO Florestal & 1360 \\
\hline 42 & Ribeira do Alecrim & 1293 \\
\hline 43 & Funchal/Obs. & 58 \\
\hline 44 & Lugar de Baixo & 15 \\
\hline 45 & Ponta do Pargo & 312 \\
\hline 46 & São Jorge & 185 \\
\hline 47 & Funchal/Lido & 25 \\
\hline
\end{tabular}


Table 2. Basic information on the precipitation data used in this study.

\begin{tabular}{|c|c|}
\hline Meteorological Data and Pluviometric Stations (PS) & Goal \\
\hline $\begin{array}{l}\text { Data referring to the period 2004/2005 to 2010/2011: of the } \\
\text { following PS: Areeiro, Curral das Freiras, Trompica, } \\
\text { Trapiche, PEF, LREC, São Gonçalo, Funchal/Obs. e } \\
\text { Camacha. }\end{array}$ & $\begin{array}{l}\text { Spatial representation of the 95th percentile of daily } \\
\text { Precipitation. }\end{array}$ \\
\hline $\begin{array}{l}\text { Annual maximum precipitation series with a duration of } \\
1 \text { day (starting at } 9 \text { a.m.) and } 2 \text { days in the Areeiro PS } \\
\text { (1961/62 to 1993/94). }\end{array}$ & Estimate the return Period. \\
\hline $\begin{array}{l}\text { Precipitations of daily and subdaily duration, referring to } \\
\text { a set of PS located on the south side of the Island. }\end{array}$ & $\begin{array}{l}\text { Analysis of the rainy episodes occurring from } 2009 \text { to } \\
\text { 2011. }\end{array}$ \\
\hline $\begin{array}{l}\text { Climatic series of daily precipitation of the Areeiro PS } \\
\text { (1961-2010) and Funchal/Obs. (1949-2010). }\end{array}$ & $\begin{array}{l}\text { Monthly distribution of the frequency of days with } \\
\text { precipitation equal to or greater than the 95th } \\
\text { percentile. }\end{array}$ \\
\hline $\begin{array}{l}\text { Climatic series of daily precipitation of Areeiro PS: } \\
\text { 1961/62 to } 1993 / 94 \text {. }\end{array}$ & $\begin{array}{l}\text { Analysis of the frequency of intense precipitation } \\
\text { days, based on the criterion of precipitation in } 24 \mathrm{~h}> \\
100 \mathrm{~mm} \text {. }\end{array}$ \\
\hline $\begin{array}{l}\text { Series of hourly precipitation data, referring to the period } \\
1980-2010 \text { ( } 31 \text { years) in Funchal/Observatory PS and in } \\
\text { the period 2002-2010 ( } 9 \text { years), in the Areeiro PS. }\end{array}$ & $\begin{array}{l}\text { Analysis of the frequency of intense precipitation } \\
\text { days, based on the criterion of precipitation in } 6 \mathrm{~h}> \\
30 \mathrm{~mm} \text {. }\end{array}$ \\
\hline
\end{tabular}

The two main meteorological stations of Funchal, Funchal/Obs. and Areeiro, were employed in the analysis of the frequency of occurrence of heavy rainfall events during the periods indicated in Table 2. The statistical summary of the events of heavy rainfall listed in Table 8 was done through the application to the Areeiro station, of the criteria of precipitation greater than $100 \mathrm{~mm}$ in $24 \mathrm{~h}$ (Section 3.1.1). Depending on the availability of hourly climatic time series, the meteorological warning criterion of the Portuguese Institute for Sea and Atmosphere (IPMA) was applied, namely the yellow level warning, that is activated when the forecast indicates a rainfall concentration greater than $30 \mathrm{~mm}$ in a mobile period of $6 \mathrm{~h}$ (Table 2). The criteria for the determination of intense precipitation events can be based on thresholds of absolute values in a given time interval $(1,3,6$, or $24 \mathrm{~h})$, or percentiles techniques, e.g., 95th or 99th percentile [38].

The technique of the 95th percentile of daily precipitation was applied in the analysis of the inter-monthly variation of intense precipitations (Table 2). The intense precipitation events that occurred between 2009 and 2011 were chosen as case studies. In just over 12 months, Madeira was hit for seven notable episodes of intense precipitation, four of which occurred in the first 4 months of 2010/2011: 21 October 2010, 25 November 2010, 20 December 2010, and 25 January 2011. The previous hydrological year (2009/2010) was also marked by the occurrence of three rainy episodes: the first on 22 December 2009, the second on 2 February 2010, and the third on 20 February 2010. Some of these events trigger a sudden rise of the flow, without necessarily corresponding to flash floods. However, for this sequence of months it was possible to have access to sub-daily data from a network of relatively dense automatic rain gauges located in Funchal and in other parts of the Island. Unlike other sequences of hydrological years, this dataset has few data gaps, which allowed us to compile and systematize information regarding typical thresholds of precipitation. The summary presented in Table 8 does not integrate information about the event of 22 December 2009, because it had greater expression only in the northern part of the Island, outside the study area, however, the values of this event were used in the creation of the regional maps of heavy rains (Figure 6A,B).

\subsection{Methods of Spatial Interpolation of Sub-Daily Precipitation}

Spatial interpolation methods allow the transformation of discrete data into spatially continuous information. When studying the spatial distribution of precipitation, the use of linear regression using altitude as an auxiliary variable was one of the most commonly used conventional multivariate 
method, before the expansion of geostatistical models, with good results in the case of total annual rainfall. However, in the case of daily and sub-daily precipitations at regional scale, the analyzed data show that the correlation between precipitation and altitude is not always strong and positive in subtropical island like Madeira, because short duration and intense rains can be more expressive in the coastal zone and intermediate altitudes (500-600 m), than in the mountains, above $1000 \mathrm{~m}$. For this reason, in some cases the application of multilinear regression may not be feasible. Therefore, a kriging method [39] was used, which is suitable especially when the density of PS is high, and these are consistently distributed throughout the territory, as is the case.

In order to better understand the structure and spatial contrasts of heavy rains, a synthesis map based on the inclusion of several levels of information available at the local and regional scale, considered to be representative of the characteristic features of short-lived intense precipitation events, was produced (Figure 2d). Thus, the average of the following spatialized parameters was computed: (a) $12 \mathrm{~h}$ and $1 \mathrm{~h}$ maximum precipitation for the seven heavy rainfall presented above. Figure 2a,b represents the average of the rainfall surfaces presented in Figure 6A,B; (b) 95th percentile of daily precipitation based on 9 PS data in the period from 2004/2005 to 2010/2011 (Figure 2c). The spatial interpolation of these parameters was performed using the ordinary kriging method [39]. Geostatistical estimation starts with the construction and interpretation of semi-variogram graphs, followed by the development of the corresponding kriging method. The identification of estimation errors results from the difference between interpolated values and the observed values, through a designated operation of cross validation, that allows comparing the effectiveness of different estimation methods [24,39]. Data processing and corresponding results in [37].

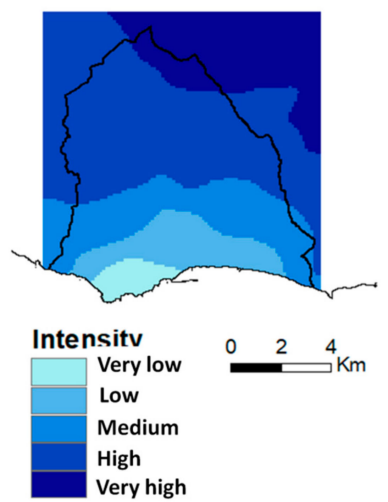

(a)

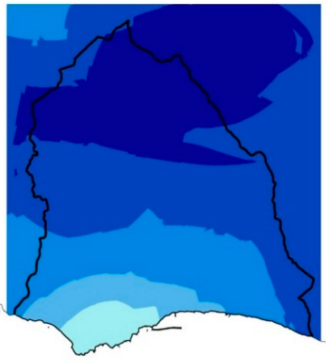

(b)

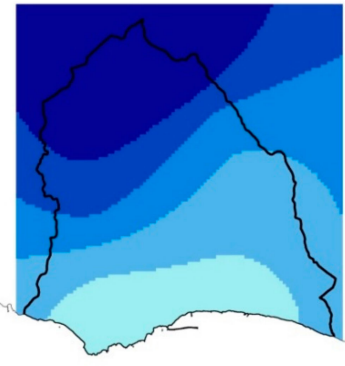

(c)

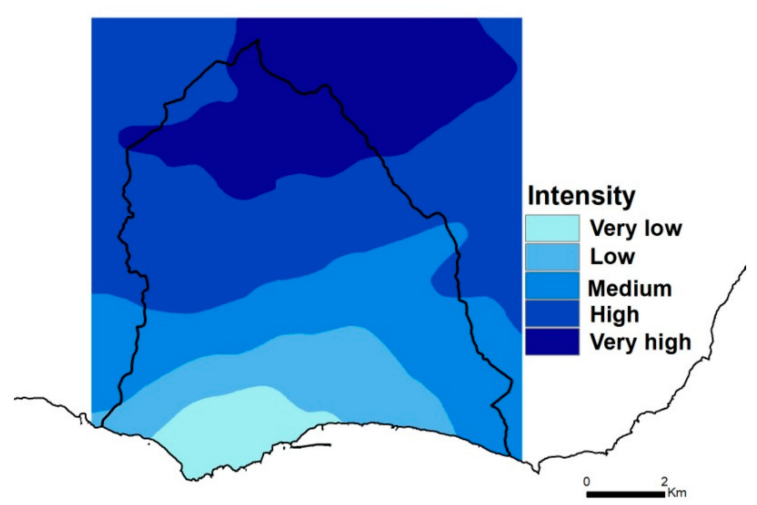

(d)

Figure 2. Spatial evaluation of intense precipitation based on: (a) and (b) average intensity of maximum precipitation in $1 \mathrm{~h}$ and $12 \mathrm{~h}$; (c) 95th percentile of daily precipitation; (d) zonation of intense precipitation levels. 


\subsection{Susceptibility Assessment Model of Mass Movements in Small Mountainous Basins}

The adopted methodology is based on the multicriteria spatial analysis of the weighted overlap of different factors (Figure 3) that influence the occurrence of extreme hydro-geomorphological processes in mountain basins. The objective of this classification is to represent the spatial contrasts regarding the predisposition of the lands to be affected by extreme precipitation events that trigger mass movements on the slopes and on the valley bottoms, towards the fluvial channels. To obtain the final map, each factor (Figure 3) was assigned a weight, given its plausible importance in the occurrence of these processes, according to the scientific literature. However, due to the existing uncertainties related to the importance of each of the selected variables in conditioning and triggering the processes under analysis, it was necessary to perform several modeling exercises, varying the relative weight assigned to each variable. It is important to emphasize that there are multiple possibilities of conjugation of weights and variables, which are affected by the subjective option adopted in this process $[18,40,41]$.

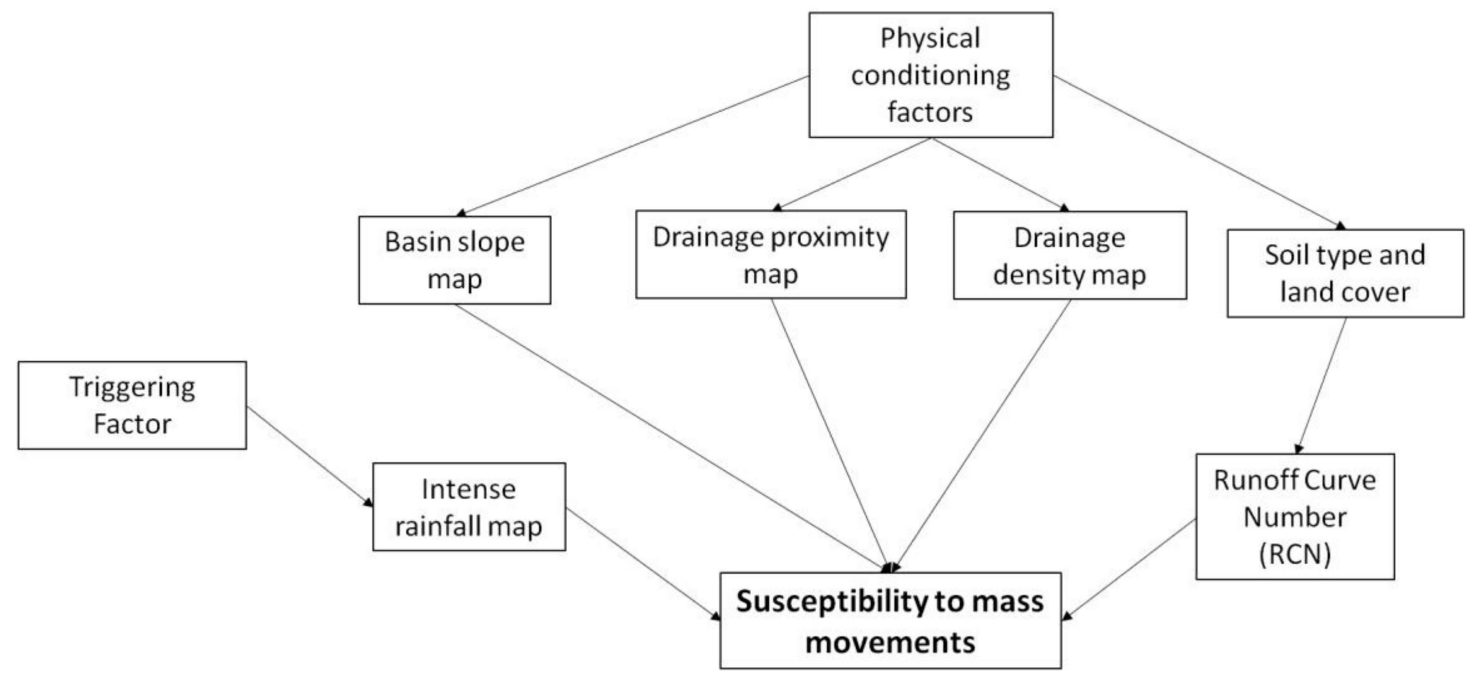

Figure 3. Conceptual scheme of the model for the evaluation of susceptibility to mass movements in Funchal.

The proposed methodology for assessing the susceptibility to the occurrence of mass movements towards and along the valley bottoms follows a workflow based on the following main steps [42]: (1) selection of sources of information about the factors considered relevant for the identification of susceptibility $[43,44]$; (2) calculation of the values of the selected variables per unit of land (cell); (3) integration of the variables in a multicriteria-analysis model, according to empirical functions that result from the degree of importance assigned to each factor; (4) validation of the model results based on historical and geomorphological information, satellite-derived data and field observations [30].

\subsection{Factors Used and Respective Weights}

Depending on the data available several variables were selected to assess the territorial susceptibility, including climate (map synthesis of heavy rainfall, according to the methodology described in the previous section), hydrology (drainage system), relief (slope), and type and occupation of the soil (with influence on water retention). The different factors of mass movements are usually grouped into two distinct sets, depending on their conditioning and triggering function. However, the way they combine to a certain consequence can be considerably distinct in time and space [43-45]. Figure 4 shows the set of variables that were selected to be included in the susceptibility assessment model; the specific characteristics of each of them and their calculation procedures are described below. Table 3 shows the variables and their respective weights, that are non-dimensional values on an increasing scale between 1 (less influence on movements) and 5 (more influence). 


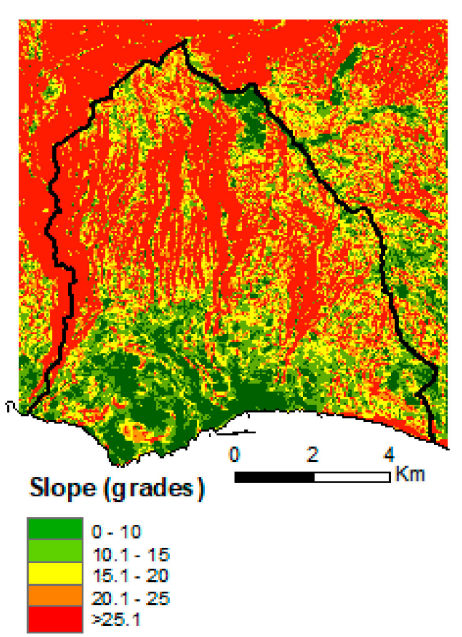

(a)

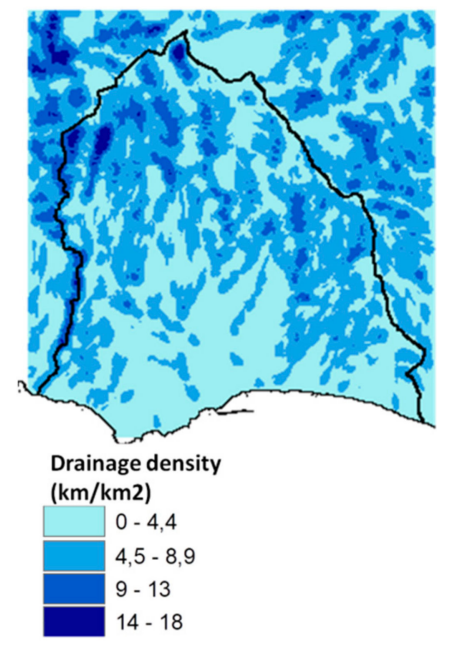

(c)

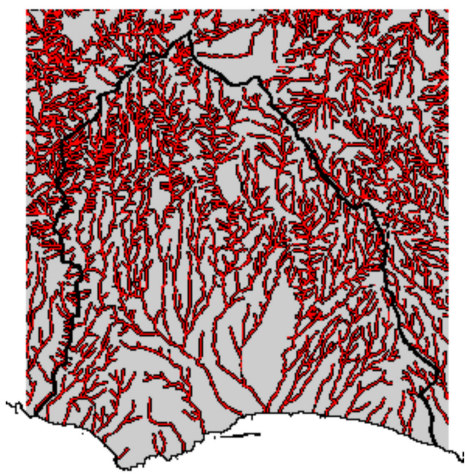

Distance from the streamline $(\mathrm{m})$

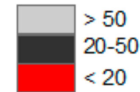

(b)

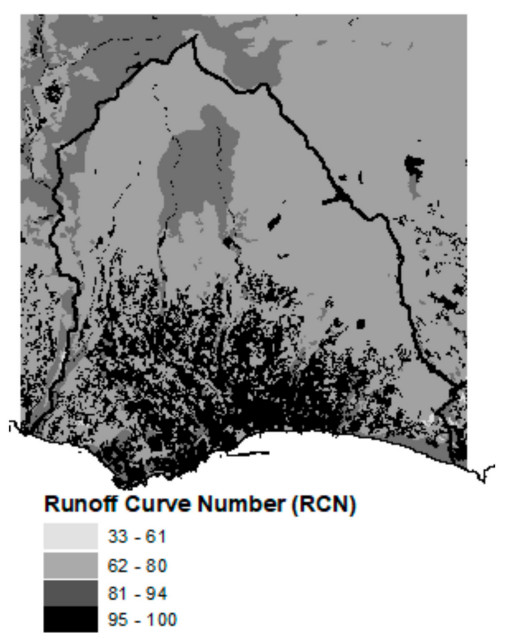

(d)

Figure 4. Variables selected to integrate the model of mass movements susceptibility in Funchal: (a) slope; (b) distance from the streamline; (c) drainage density; (d) Runoff Curve Number (CN), and zonation of intense precipitation levels indicated in Figure $2 \mathrm{~d}$.

Table 3. Variables and weights considered in the susceptibility model.

\begin{tabular}{|c|c|c|c|}
\hline Variables & Number of Classes & Variables Classes & Weight \\
\hline \multirow[t]{5}{*}{ Slope } & \multirow[t]{5}{*}{5} & $0-10^{\circ}$ & 1 \\
\hline & & $10-15^{\circ}$ & 2 \\
\hline & & $15-20^{\circ}$ & 3 \\
\hline & & $20-25^{\circ}$ & 4 \\
\hline & & $>25^{\circ}$ & 5 \\
\hline \multirow[t]{3}{*}{ Distance from the streamline } & \multirow[t]{3}{*}{3} & $>50 \mathrm{~m}$ & 1 \\
\hline & & $20-50 \mathrm{~m}$ & 4 \\
\hline & & $<20 \mathrm{~m}$ & 5 \\
\hline
\end{tabular}


Table 3. Cont.

\begin{tabular}{|c|c|c|c|}
\hline Variables & Number of Classes & Variables Classes & Weight \\
\hline \multirow[t]{4}{*}{ Drainage density } & \multirow[t]{4}{*}{4} & $0-1.6 \mathrm{~km} / \mathrm{km}^{2}$ & 4 \\
\hline & & $1.6-3.6 \mathrm{~km} / \mathrm{km}^{2}$ & 3 \\
\hline & & $3.6-5.5 \mathrm{~km} / \mathrm{km}^{2}$ & 2 \\
\hline & & $5.5-13.7 \mathrm{~km} / \mathrm{km}^{2}$ & 1 \\
\hline \multirow{5}{*}{$\begin{array}{l}\text { Intensity of precipitation } \\
\text { (see Figure 2) }\end{array}$} & \multirow[t]{5}{*}{5} & Very low & 1 \\
\hline & & Low & 2 \\
\hline & & Medium & 3 \\
\hline & & High & 4 \\
\hline & & Very high & 5 \\
\hline \multirow[t]{2}{*}{ Type and occupation of the soil } & \multirow[t]{4}{*}{4} & $\mathrm{CN}<61$ & 1 \\
\hline & & $\mathrm{CN}>=62 \mathrm{e}<=80$ & 2 \\
\hline \multirow[t]{2}{*}{ Runoff Curve Number (CN) } & & $\mathrm{CN}>=81 \mathrm{e}<=94$ & 3 \\
\hline & & $\mathrm{CN}>=95$ & 4 \\
\hline
\end{tabular}

\subsubsection{Slope}

Among all the physical variables, the slope is the one that has the greatest influence on the formation of mass movements, surface runoff, and flash floods on Madeira, because it is a mountainous island with considerable altimetric differences, cut by deep, narrow entrenched valleys. The higher the gradient of the slopes and of the fluvial channels the smaller the infiltration, the shorter the time of formation of flow concentrated in the streams and the greater the velocity of the flow. Under these circumstances, higher peak flow will be produced, and higher will be the potential energy of the runoff and the hydric erosion in the slopes and the fluvial erosion processes, hence the capacity of transporting solid material is also higher [46,47]. Considering the relief characteristics of the island of Madeira, five intervals of slope classes were defined (Table 3), from very low $\left(0-10^{\circ}\right)$ to very steep slopes $\left(>25^{\circ}\right)$. In natural slopes, the likelihood of instability generally occurs where the source area and immediate down slope angle is greater than about $25^{\circ}$ but can occur on slopes down to about $18-20^{\circ}$ [48]. These reference values were considered in the adoption of the slope classes. The basic information used in the calculation of the slope map derives from a digital terrain model with a resolution of $100 \mathrm{~m}^{2}$, which allows having a rigorous survey of the physical characteristics of the terrain.

\subsubsection{Drainage Network (Distance from the Drainage Network and Drainage Density)}

The cartographic representation of the space or distance to the drainage network has the objective of defining different riverbank ranges, as a function of the distance measured from the axis of the streamline and considering that the smaller the distance, the greater the tendency for the occurrence of extreme hydrological phenomena. The drainage proximity map was generated by the Multiple Buffer operator of the ArcGIS-10.3 Analysis Tools.

The drainage density is defined as the ratio of the total length of the watercourses of a given region or river basin to its total area. It is a suitable parameter to evaluate the degree of dissection of the terrain and the current forms of relief. High values of drainage density indicate that there is a high number of fluvial segments per unit area, which can result in a faster response to intense rainfall events with lower concentration times. Higher values of drainage density suggest that soils tend to be less permeable, which, over time, favors the formation of organized runoff and the intensification of peak flows [49-51]. However, from the perspective of the dynamics of mass movements, it is assumed that the lower the value the greater the susceptibility of the terrain to the processes of hydric erosion and mass movements, so the assigned weight is inverted. The drainage density was calculated using 
ArcGIS-10 Spatial Analyst tools, namely the line density function. The values obtained were divided into four classes considering natural discontinuities. The highest drainage densities, above $4.5 \mathrm{~km} / \mathrm{km}^{2}$ occur mainly in the intermediate and upper sectors of the basins of the study area.

\subsubsection{Type and Occupation of the Soil}

The influence of natural and anthropogenic permeability on the direct surface runoff is evaluated by applying the Soil Conservation Service's Curve Number $(\mathrm{CN})$ Method [52,53]. The spatial distribution of $\mathrm{CN}$ was obtained from the crossing in ArcGIS of information related to: (a) soil type (Madeira Island soil chart published in 1992); (b) land cover (2007 land cover chart). In practice, the method assumes that infiltration is a function of soil type and its use.

The Soil Conservation Service (SCS), according to which soils can be classified into four types (A, B, C, and D) (with increased capacity to generate runoff at the surface), can be used to quantify the Runoff Curve Number (RCN) [54]. The hydrological soil type map was developed considering the characteristics of the soil types shown in the Soil Chart, in particular, the aspects that allow determining its degree of permeability and following the classification rules of the hydrological type of soil. It is assumed that the types of dominant soils reflect the dominant geological characteristics of the land.

The existing designations of land cover/land use maps (COS, 2007) were grouped into five classes, according to their nature: built-up areas (urban, commercial), agricultural areas (including the subgroup "pastures"), uncultivated land, and forest areas. In general, soil sealing due to the urbanization process, reduces infiltration and tends to produce a greater runoff flow, resulting in increased flow velocity and maximum flood flow [55], mainly in consolidated urban areas.

The Runoff Curve Number depends on the hydrological type of the soil, its use and on the surface conditions. The RCN was calculated with ArcGIS through the process of joining the combined attributes of maps of the hydrological type of soil and soil occupation. In practice, a new field was added to the map resulting from this union, filled in according to the two values related to land use codes and soil types, according to the $\mathrm{CN}$ reference values (Table 4). Therefore, the indications for agricultural, urban, suburban and rural regions were considered in the determination of RCN according to the SCS [56]. In theory, the RCN ranges from 0 (maximum permeability) to 100, in which case the grounds would be totally impervious.

Table 4. Curve Number (CN) from soil type data (1992) and soil occupation (2007) in Funchal. Tabulated values.

\begin{tabular}{lcccc}
\hline \multicolumn{1}{c}{ Description of Land Use } & \multicolumn{5}{c}{ Hydrologic Soil Group } \\
\hline Urban/built areas & A & B & C & D \\
\hline Industry and commercial areas & 89 & 92 & 94 & 95 \\
\hline Agricultural areas & 62 & 71 & 78 & 81 \\
\hline Uncultivated land & 39 & 61 & 74 & 80 \\
\hline Forests & 33 & 57 & 71 & 78 \\
\hline
\end{tabular}

\subsubsection{Precipitation}

In order to integrate this level of information into the mass movements susceptibility assessment model, the different values of precipitation were grouped into five classes of precipitation intensity with increasing weights: 1-very low, 2-low, 3-medium, 4-high, 5-very high (Table 5), thus enabling their standardization with a scale of dimensionless values (Figure 2d). The susceptibility analysis uses a relative scale of values, usually without a unit of measurement and provides spatialized information about the potential occurrence of floods. The scale of absolute precipitation values for the duration of $1 \mathrm{~h}$ and $12 \mathrm{~h}$ shown in Table 5 comes from the scale of spatialized data obtained for 
the group of rain events studied in this research and from the map of the 95th percentile of daily precipitation (Section 2.1).

Table 5. Ranking of precipitation intensity levels for different time durations.

\begin{tabular}{cccccc}
\hline $\begin{array}{c}\text { Maximum Hourly } \\
\text { Precipitation } \\
\text { (mm) }\end{array}$ & Intensity Level & $\begin{array}{c}\text { Maximum } \\
\text { Precipitation at } \\
\mathbf{1 2} \mathbf{~ h ~ ( m m ) ~}\end{array}$ & Intensity Level & $\begin{array}{c}\text { 95 Percentile of } \\
\text { Daily Precipitation } \\
\text { (mm) }\end{array}$ & Intensity Level \\
\hline $0-10$ & 1 & $0-60$ & 1 & $30-40$ & 1 \\
\hline $10-20$ & 2 & $60-90$ & 2 & $40-50$ & 2 \\
\hline $20-30$ & 3 & $90-120$ & 3 & $50-60$ & 3 \\
\hline $30-40$ & 4 & $120-150$ & 4 & $60-70$ & 4 \\
\hline$>40$ & 5 & $>150$ & 5 & $>70$ & 5 \\
\hline
\end{tabular}

The space-time variability of rainfall is particularly important in strongly urbanized basin sectors, which is why recent studies have drawn attention to this issue [26-29]. In urban areas, the hydrological processes are characterized by strong temporal and spatial variability and tend to respond quickly to small-scale temporal and spatial variations of rainfall [57].

\subsection{Criteria for Weighting and Validating the Model}

The results of the factors were divided into a variable number of classes, which in the case of some factors had equal amplitudes, and variable amplitudes for others, as shown in Table 3. Thus, for each factor, an increasing weight was assigned to each class (or decreasing weigh in the case of drainage density) with the objective of quantifying the lesser or greater susceptibility to mass movements.

The weighting criterion was used in the adopted risk assessment model. The factors were ordered assuming, accordingly with scientific literature $[45,58]$, that there are some more preponderant than others, 1 being the most important factor (slope) and 4 (drainage density) with less relative influence. Each factor is assigned a relative weight, which is standardized as a function of the sum of their assigned weights (Table 6).

Table 6. Composite index for the evaluation of mass movements susceptibility in Funchal.

\begin{tabular}{lccc}
\hline \multicolumn{1}{c}{ Variables } & Importance of the Factor & Factor Weight & Standardisation \\
\hline Slope & 1 & 5 & 0.278 \\
\hline Distance from the streamline & 3 & 3 & 0.167 \\
\hline Type and occupation of the soil & 2 & 4 & 0.222 \\
\hline Drainage density & 4 & 2 & 0.111 \\
\hline Intensity of precipitation & 2 & 4 & 0.222 \\
\hline Sum & & 17 & 1 \\
\hline
\end{tabular}

It was decided to assign a maximum weight of 5 to the slope factor, as it has a direct influence on the potential energy of the water and on the flow velocity. In second degree of importance were included two factors which were assigned a weight of 4 : the type and use of the soil and the precipitation intensity. The first, results from a combination of variables that significantly condition soil permeability and runoff formation, and hence the time of concentration and the magnitude of the peak flows. The second is related to the triggering factor of the mass movements and the fluvial runoff and although there may be randomness in its spatial distribution in regions of mountainous relief, as is the case, short-term rainfall tends to be more intense at higher altitudes, as suggested by the results of the map obtained by the methodology described above. The distance from the drainage network is the third most important variable of the final model chosen and was assigned a weight of 3 . This was considered the most appropriate physical variable to show the spatialization of hazard in the fluvial environment, 
as far as it allows the definition of different riverbank widths for the safety of people and goods, which is an important aspect in the definition of guidelines and standards for fluvial land use planning and the planning of hydrological risk areas. The drainage density was chosen as the last variable of the model, to which a weight of 2 was attributed. This is an important variable to identify the soils that are most susceptible to the occurrence of hydric erosion processes and mass movements, resulting from unorganized runoff, in the areas of lower drainage density.

The final result shows the classification of the territory concerning the factors that influence its behavior in a situation of intense precipitation. As explained previously, the present methodology pre-selects a set of variables that are considered determinants to condition and trigger the occurrence of mass movements towards and along the fluvial channels. The determination of the best susceptibility map results from an iterative process, in which different weights are assigned to the selected variables until the obtained result is more consistent with the occurrence history, in terms of spatial incidence.

Model validation was performed through the analysis of the spatial comparison between the localization of the mass movements recorded in the past, some of which were already studied by other authors [30], and the classes of susceptibility obtained by the model. The polygons locations of the past events (1945-2011) were inserted on the susceptibility map for visual validation. The degree of adjustment between the observed data and the model is determined by calculating the predicted rate curve (Figure 5). The area under the curve (AUC) approach [59] was used, and the result (AUC $=0.728$ ) showed that the map obtained from the model gives a relative suitable accuracy in classifying the areas prone to occurrence of mass movements, on a scale ranging from 0 (minimum performance) to 1 (maximum performance).

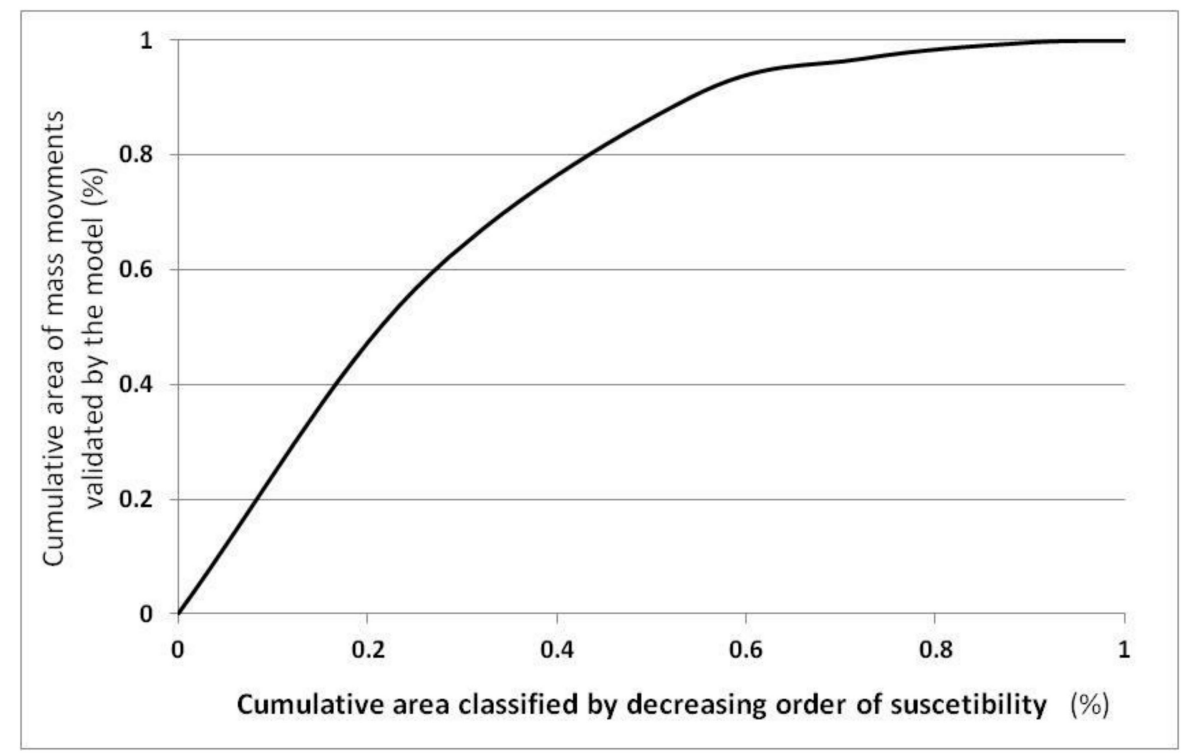

Figure 5. Predicted curve of the mass movements susceptibility map, applied to Funchal Municipality.

\section{Results}

The results were divided into two main parts, the first one focuses on the analysis of the spatial incidence and statistical characterization of the intense precipitation events, and the second presents the model of susceptibility to mass movements and the results of its application to the municipality of Funchal.

\subsection{Evaluation of the Spatial Incidence of Intense Precipitation Events}

This section presents firstly an inventory of the intense precipitation events that occurred between 1945 and 2011, and consequent mass movements and flash floods generated in the southern slopes of the Island (Table 6). The following is a brief statistic of the number of days of intense precipitation in 
study area, at low altitude (Funchal/Obs.) and in the mountain (Areeiro); a second more developed section deals with data characteristic of the notable precipitation events that occurred in the period from 2009 to 2011.

\subsubsection{Identification of Intense Precipitation Events}

Taking into account the importance of precipitation in the occurrence of mass movements with catastrophic consequences, an inventory of the heavy rainfall events that took place on the southern slope of Madeira between 1945 and 2011 was carried out, by consulting the descriptive reports of the impacts on society [60]. These included at least one victim (dead, missing, or injured), several affected persons (evacuated or evicted), and damage in public or private infrastructures, housing, commerce, transport, and communications. Although there was no significant damage caused by the last four events listed in Table 7, we chose to integrate them into the present analysis, given the richness of recorded precipitation information, which corresponded to sudden increases in river flow in the study area, with transport of solid material from de upper part of the basins to the urban reach. The available documented information relating to the occurrence of natural disasters in Madeira, allowed a very faithful reconstitution of what happened within the studied period. Unfortunately, the available precipitation series of the oldest weather stations in Funchal do not fully cover the period of the studied years.

Table 7. Intense precipitation events, mass movements and flash floods that occurred between 1945 and 2011 on the southern slope of the island of Madeira.

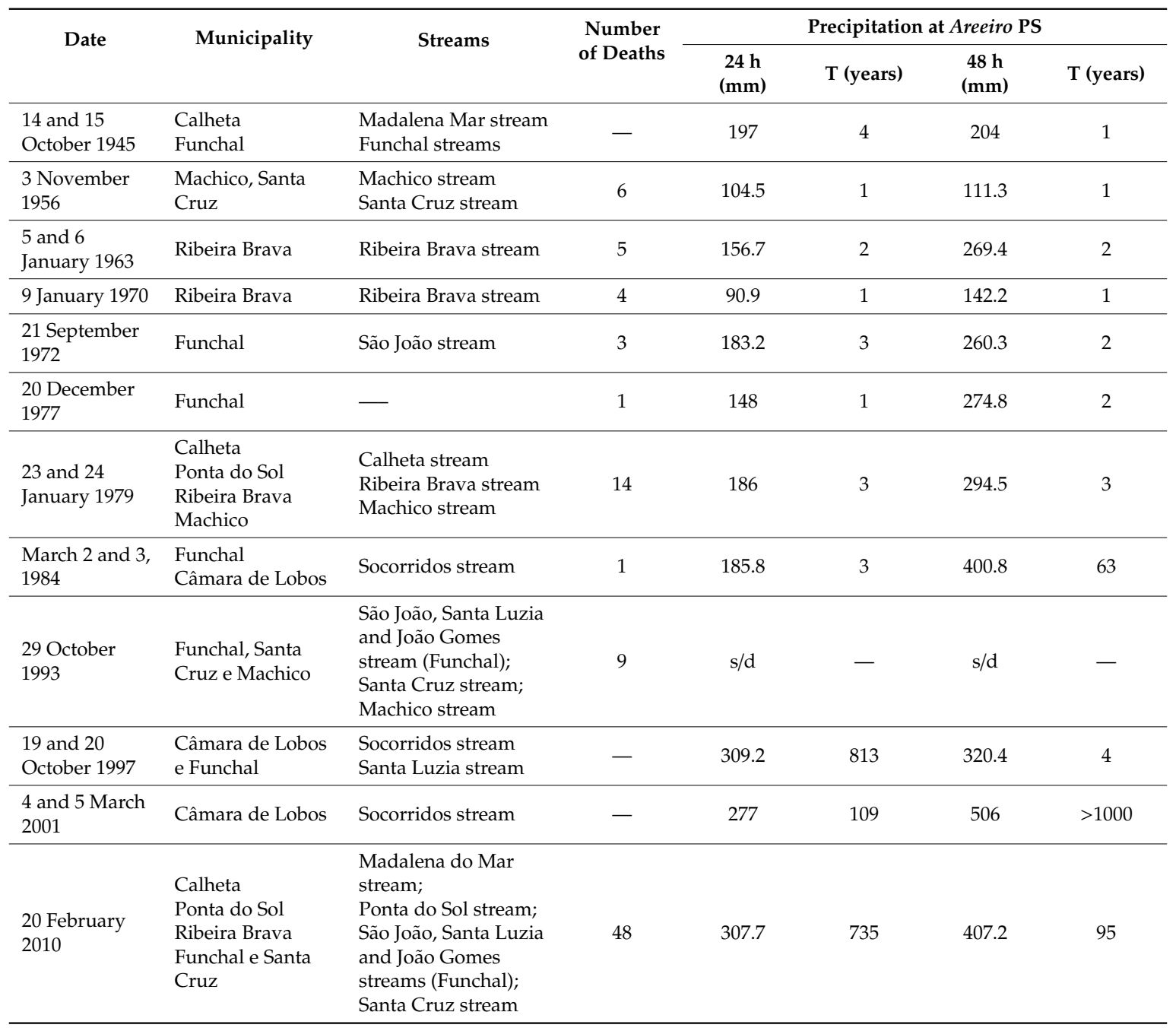


Table 7. Cont.

\begin{tabular}{|c|c|c|c|c|c|c|c|}
\hline \multirow{2}{*}{ Date } & \multirow{2}{*}{ Municipality } & \multirow{2}{*}{ Streams } & \multirow{2}{*}{$\begin{array}{l}\text { Number } \\
\text { of Deaths }\end{array}$} & \multicolumn{4}{|c|}{ Precipitation at Areeiro PS } \\
\hline & & & & $\begin{array}{l}24 \mathrm{~h} \\
(\mathrm{~mm})\end{array}$ & $\mathrm{T}$ (years) & $\begin{array}{l}48 \mathrm{~h} \\
(\mathrm{~mm})\end{array}$ & $\mathrm{T}$ (years) \\
\hline $\begin{array}{l}21 \text { October } \\
2010\end{array}$ & Funchal & São João stream & - & 147 & 1 & 150.5 & 1 \\
\hline $\begin{array}{l}25 \text { and } 26 \\
\text { March } 2010\end{array}$ & Funchal & - & - & 185.2 & 3 & 190.7 & 1 \\
\hline $\begin{array}{l}20 \text { December } \\
2010\end{array}$ & $\begin{array}{l}\text { Câmara de Lobos } \\
\text { e Funchal }\end{array}$ & Socorridos stream & - & 165 & 2 & 204.2 & 1 \\
\hline $\begin{array}{l}25 \text { January } \\
2011\end{array}$ & Funchal & Funchal streams & - & 321 & $>1000$ & 377.7 & 21 \\
\hline
\end{tabular}

The return periods of the values associated to the inventoried rainfall events were calculated based on the series of annual maximum rainfall with duration of 1 day ( $24 \mathrm{~h}$ starting at $9 \mathrm{~h}$ ) and 2 days in the Areeiro PS, from 1961/1962 to 1993/1994 (Table 2) because it corresponds to a continuous series, without exclusion of years and with few partial failures. The constitution of longer climate series is often conditioned by existing weather observation failures, as is the case for the period between 1936 and 1961 in Areeiro PS. The analysis of daily precipitation in the interval from 9:00 to 9:00 the next day result from the fact that there was a period, in which readings of weather observations were performed only once a day, a procedure that conditions the assessment of the normal of maximum annual values with the duration of one day, and contributes to the introduction of a difficult-to-assess error in the clearance of the actual magnitude of a given precipitation episode. Therefore, the determination of the return period will also be affected. For this reason, the values of Table 7 are not in accord with values published in previous papers [61,62].

Sixteen events of intense precipitation were recorded in the inventory period, resulting in a mixture of mass movements and flash floods in the different streamlines that run along the southern slope of the Island, nine of which caused 91 deaths (Table 7). The event of 20 February, 2010 was the deadliest, with 48 confirmed dead, 22 of which in the municipality of Funchal. Between 2011 and 2019 the study area was not affected by heavy rain events. However, there were two extreme hydro-geomorphological events in November 2012 and November 2013 that caused substantial damages, but only in the northern side of the Island.

In general, it was observed that in $90 \%$ of the events listed the precipitation was greater than $150 \mathrm{~mm}$ in $24 \mathrm{~h}$. The average precipitation during the events that had a higher incidence in Funchal was $222 \mathrm{~mm}$ in $24 \mathrm{~h}$ at the top of the mountain (in Areeiro). These high values of daily precipitation are not very frequent; indeed, in the 33 years of the climatic series (1961/62-1993/94) of that station, there were 130 days with precipitation equal to or greater than $100 \mathrm{~mm}$ in $24 \mathrm{~h}$. According to the data treated, intense precipitation events can contribute decisively to the increase of the monthly and semester precipitation. For example, the total daily precipitation of only four rainy events that occurred in 2010/2011 (in some places in Funchal, PS Trapiche), is equivalent to 37\% of the accumulated precipitation in the first semester of the respective hydrological year. This tendency shows that rainfall is not necessarily frequent and/or persistent, but it is intense, determining a rainfall regime with marked inter-daily variation.

Mass movements and the flow of solid material in water courses are triggered by events of intense precipitation that are usually very concentrated in time but also in space. The inventory data (Table 7) shows that Funchal is the area of the south part of the Island that was more often affected, particularly the hills corresponding to the headwaters of the three main basins (São João, Santa Luzia, and João Gomes streams). 


\subsubsection{Main Features and Spatial Incidence of Intense Precipitation Events}

Regarding the events that occurred from 2009 to 2011 as case studies, it should be noted that the hydrological years of 2009/2010 and 2010/2011 were very rainy. In the Areeiro station, the total accumulated precipitation of the 1st semester of each hydrological year mentioned above was, respectively, $90 \%$ and $46 \%$ above the average amount computed over a 60 -year period (1949/1950-2008/2009). The highest values of precipitation occurred on 20 February, 2010 [62]. The paper published by [63] regarded the events that occurred in the year 2009/2010 as remarkable, and the atmospheric characteristics associated to these events as well as the effects of the relief of the Island in the intensification of orographic precipitation generation were analyzed.

Considering the values shown in Table 8, precipitation storms are associated with daily values varying from 95 to $140 \mathrm{~mm}$ in places below $200 \mathrm{~m}$ of altitude, whereas in mountain areas above $500 \mathrm{~m}$ the precipitation values tend to be higher, namely between $195 \mathrm{~mm}$ and $225 \mathrm{~mm}$.

Table 8. Summary of precipitation values associated with intense events from 2009 to 2011.

\begin{tabular}{|c|c|c|c|c|c|c|c|c|c|}
\hline & & Trompica & $\begin{array}{l}\text { Curral } \\
\text { Freiras }\end{array}$ & Trapiche & $\begin{array}{c}\text { São } \\
\text { Martinho }\end{array}$ & Areeiro & $\begin{array}{c}\text { Parque } \\
\text { Ecológico }\end{array}$ & $\begin{array}{c}\text { São } \\
\text { Gonçalo }\end{array}$ & Camacha \\
\hline \multirow{3}{*}{2 February 2010} & DP & 179.4 & 390 & 144.4 & 95.4 & 184.7 & 266.6 & 208 & 248.4 \\
\hline & $\mathrm{D}$ & $\begin{array}{l}18 \mathrm{~h} 50 \\
\min \end{array}$ & $+24 \mathrm{~h}$ & 20 h 00 & $16 \mathrm{~h} 00$ & 22 h 00 & $+24 \mathrm{~h}$ & 15 h 50 & 17 h 50 \\
\hline & MHP & 28.4 & 46.6 & 27.6 & 20.4 & 24.6 & 29 & 42.4 & 33.8 \\
\hline \multirow{3}{*}{20 February 2010} & DP & 240.8 & 153.2 & 340.2 & 139.6 & 333.8 & 332.4 & 187.2 & 351 \\
\hline & $\mathrm{D}$ & 13 h 30 & 13 h 50 & 15 h 40 & $14 \mathrm{~h} 00$ & 15 h 40 & $17 \mathrm{~h} 00$ & $13 \mathrm{~h} 30$ & $14 \mathrm{~h} 00$ \\
\hline & MHP & 60.4 & 48.4 & 98.6 & 42.2 & 64.6 & 52.8 & 72.6 & 114.4 \\
\hline \multirow{3}{*}{21 October 2010} & DP & 167.6 & 71.8 & 197.6 & 120.8 & 157.2 & 144.2 & 112 & 177.6 \\
\hline & $\mathrm{D}$ & 11 h 50 & $7 \mathrm{~h} 00$ & 10 h 50 & $9 \mathrm{~h} 00$ & 11 h 50 & $10 \mathrm{~h} 00$ & 13 h 00 & 15 h 00 \\
\hline & MHP & 41 & 35.8 & 69.8 & 38.4 & 31.5 & 31.2 & 40.2 & 63.2 \\
\hline \multirow{3}{*}{$\begin{array}{l}25 \text { November } \\
2010\end{array}$} & DP & 155.8 & 43.2 & 177.4 & 129.8 & 160.5 & 166.4 & 156.4 & 193.2 \\
\hline & $\mathrm{D}$ & 15 h 40 & 6 h 20 & 15 h 20 & 17 h 00 & 17 h 50 & $20 \mathrm{~h} 00$ & 12 h 00 & 13 h 00 \\
\hline & MHP & 26.6 & 18.2 & 38.4 & 37.8 & 27.9 & 42.2 & 41 & 57.2 \\
\hline \multirow{3}{*}{$\begin{array}{l}20 \text { December } \\
2010\end{array}$} & DP & 63 & - & 115.4 & 41.4 & 165 & 121.6 & 25.4 & 66.4 \\
\hline & $\mathrm{D}$ & $12 \mathrm{~h} 00$ & - & $6 \mathrm{~h} 10$ & $5 \mathrm{~h} 00$ & 14 h 20 & $9 \mathrm{~h} 00$ & $4 \mathrm{~h} 30$ & $6 \mathrm{~h} 40$ \\
\hline & MHP & 5.2 & - & 33.6 & 17.4 & 30.1 & 29.6 & 7.8 & 17 \\
\hline \multirow{3}{*}{25 January 2011} & DP & 181.4 & - & 203.8 & 65.4 & 344.1 & 253.2 & 157 & 207.4 \\
\hline & $\mathrm{D}$ & $17 \mathrm{~h} 10$ & - & 15 h 30 & $15 \mathrm{~h} 00$ & 15 h 10 & $21 \mathrm{~h} 00$ & 14 h 50 & 15 h 50 \\
\hline & MHP & 23 & - & 24 & 9.4 & 37.3 & 25.6 & 18.2 & 25.6 \\
\hline
\end{tabular}

DP—daily precipitation (00:00 h-24:00 h). D-duration of precipitation. MHP-maximum $\mathrm{H}=$ hourly precipitation at moving interval.

According to the yellow warning criterion (Section 2.1, >30 mm/6 h), the frequency of intense precipitation events in Areeiro is on average 18 days a year (series of sub-daily values from 2002 to 2010 referenced in Table 2); nevertheless, in 2005, 2009, and 2010 this threshold was exceeded in more than 25 days of each year and attained a maximum of 33 days in the last year. Conversely, near the coast (Funchal/Obs.) the same threshold value occurred only in 3 days/year. According to the statistical summary of Table 8 , the typical values of maximum hourly rainfall recorded, especially in the areas above $600 \mathrm{~m}$ vary between 30 and $60 \mathrm{~mm}$.

As mentioned in the description of the study area, the spatial distribution of intense precipitation in Funchal tends to be influenced by the dynamic effects induced by the relief; this hypothesis gains weight if we consider the spatial structure of the intense precipitations shown in some of the maps related to the maximum 12-h and 1-h rainfall recorded in a series of rainy events between 2009 and 2011(Figure 6). 
Maximum precipitation for $12 \mathrm{~h}$
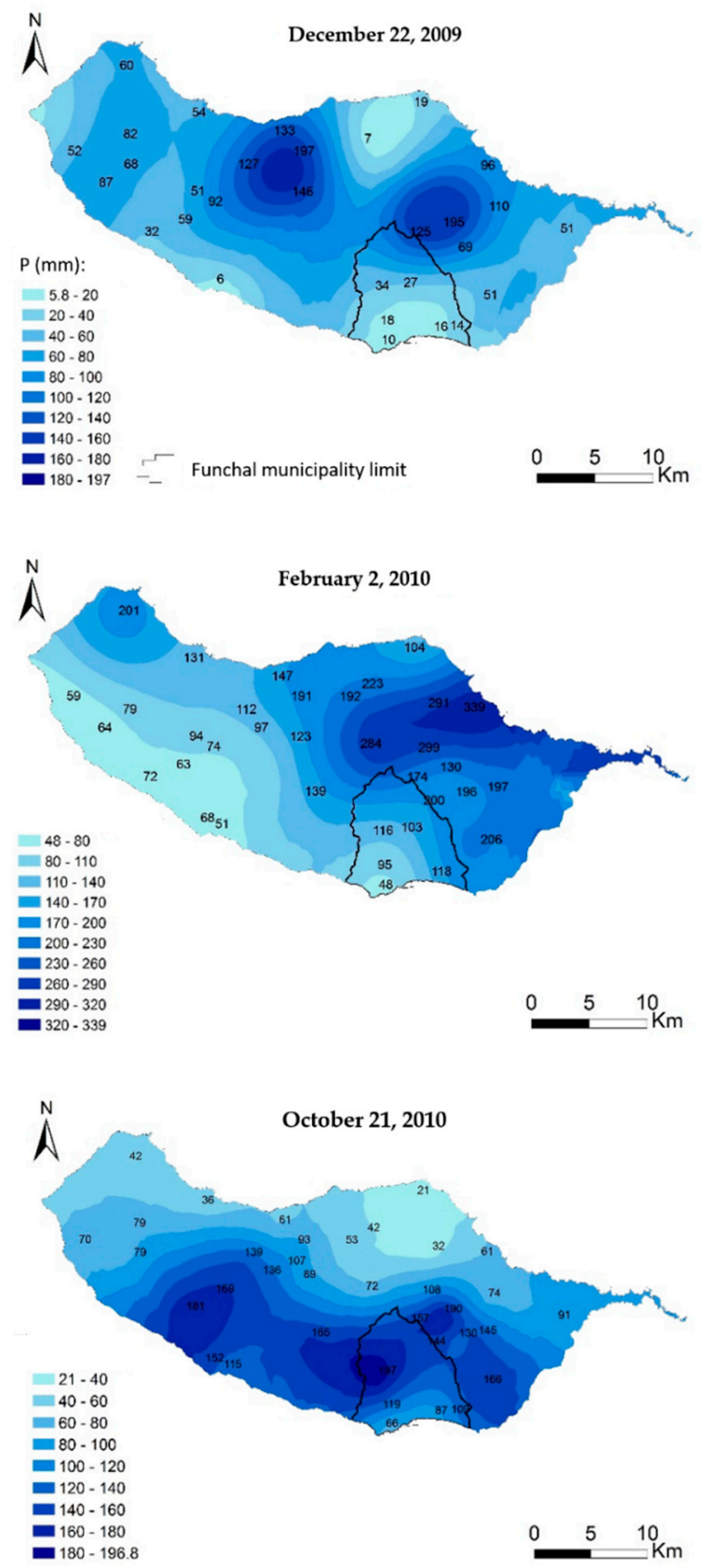

Maximum precipitation for $1 \mathrm{~h}$
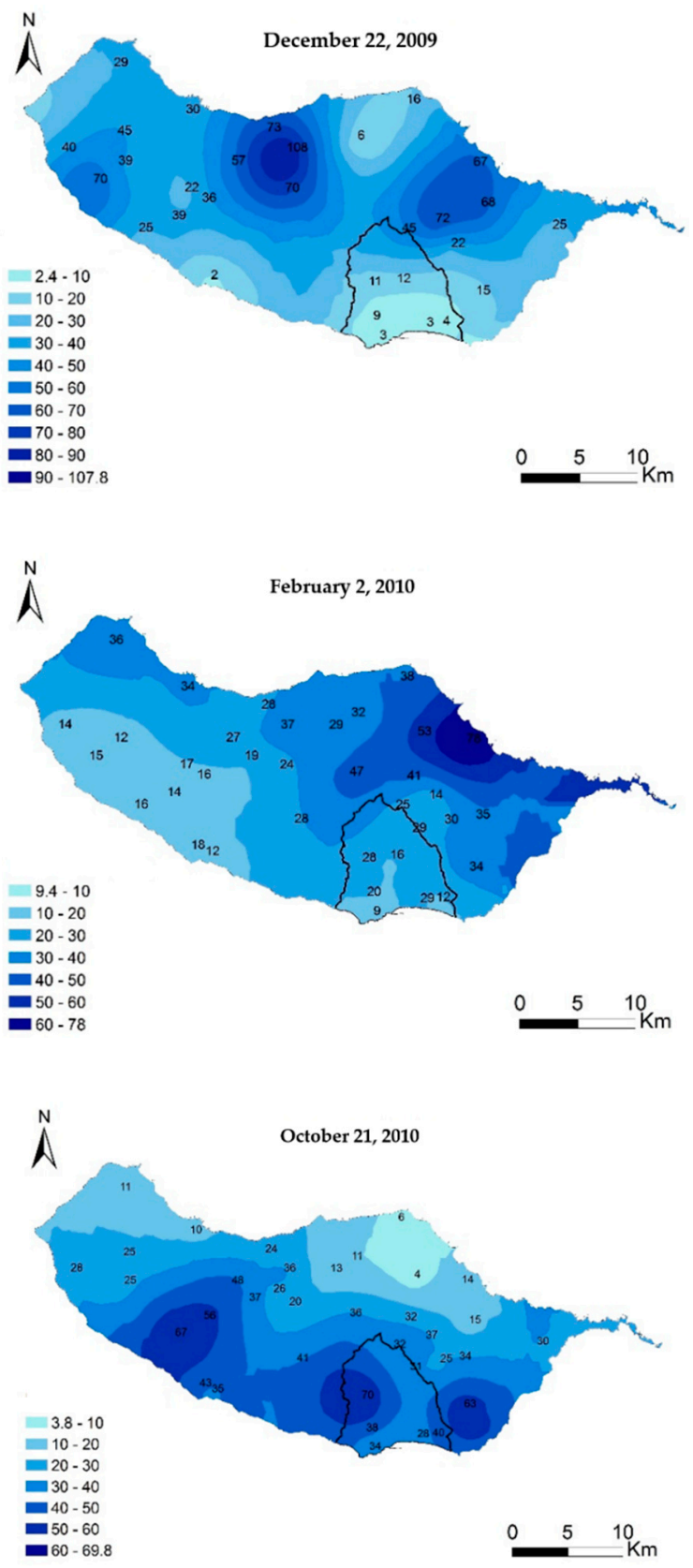

(A)

Figure 6. Cont. 
Maximum precipitation for $12 \mathrm{~h}$
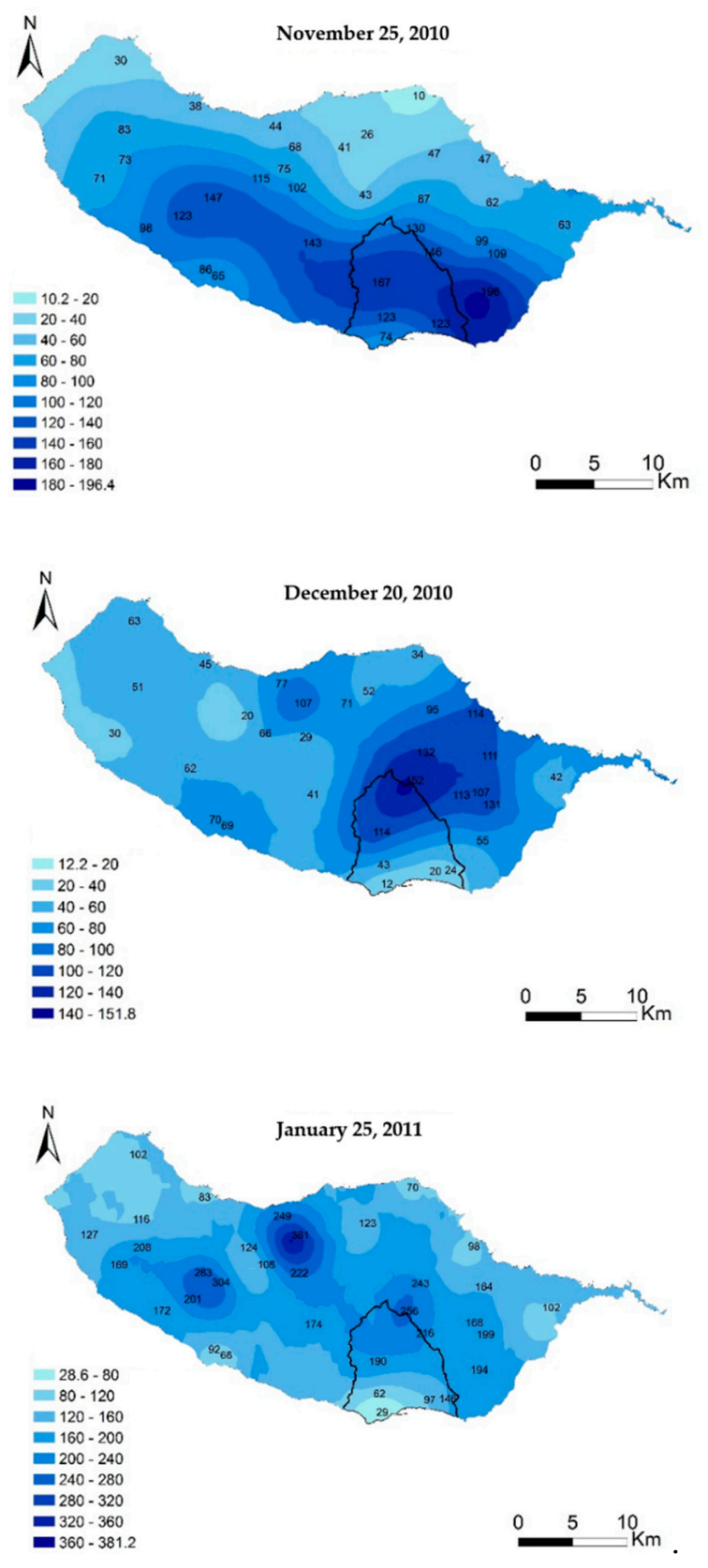

Maximum precipitation for $1 \mathrm{~h}$

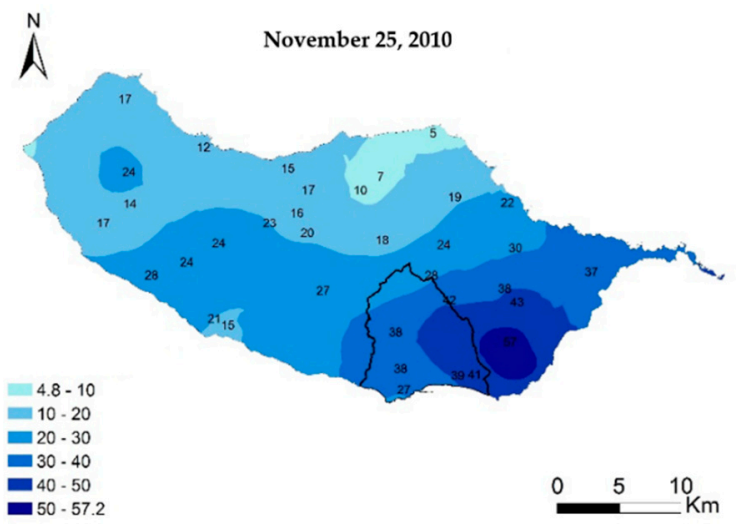

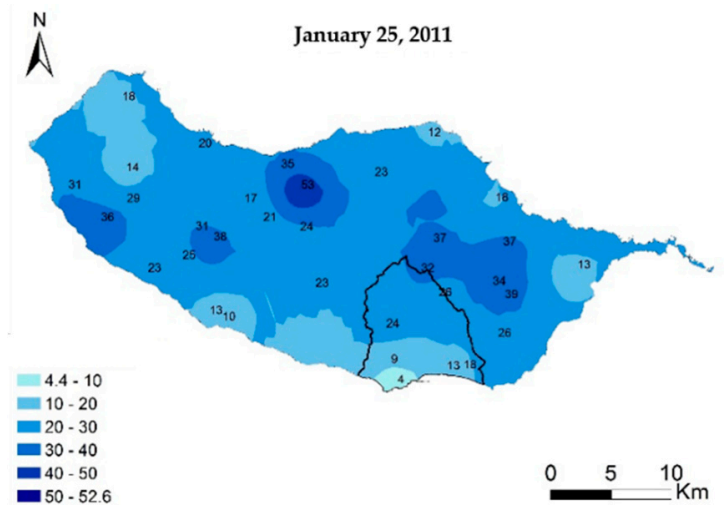

(B)

Figure 6. Spatial distribution of maximum precipitation at $12 \mathrm{~h}$ (left panels) and at $1 \mathrm{~h}$ (right panels), in a group of rainy episodes that occurred between 2009 and 2011. 6A: 22 December 2009; 2 February 2010; 21 October 2010 and 6B: 25 November 2010; 20 December 2010; 25 January 2011.

The knowledge of the singularities of the local distribution of intense precipitation presumes a detailed spatial analysis, which is often conditioned by the low temporal and spatial representativeness of the available data. The 95th percentile map of the daily precipitation (Figure 2c) was made based on the available series of daily precipitation data (2004/2005-2010/2011) of a set of PSs located in Funchal and its periphery (Figure 1, Table 1). Although the climatic series used is short, the number of PSs in operation in that period, with no data missing, is quite satisfactory. 
The spatial distribution of this statistical parameter shows that extreme precipitation events are very heavy, over $60 \mathrm{~mm}$, in the north and northwest of the municipality, along a band that runs diagonally from SW to NE between $500 \mathrm{~m}$ of altitude and the highest mountains of Funchal, over $1000 \mathrm{~m}$; the precipitation reaches a maximum of over $80 \mathrm{~mm}$ in the rocky peaks of the Areeiro. In the urban area of Funchal, roughly $300 \mathrm{~m}$ above sea level, the 95th percentile of daily precipitation is less than $40 \mathrm{~mm}$.

The attempts to estimate the patterns of spatial distribution of extreme events of precipitation have been performed with the purpose of relating them to the location of mass movements [64-67]. However, the spatial variability of precipitation in the mountains has not been sufficiently studied at a more detailed scale and, therefore, is not fully understood. For example, high resolution atmospheric models can also be used to get spatialized data in intense precipitation events [68]. It is important to comprehend whether there is a typical spatial incidence of intense precipitation storms in a given region and a subsequent strong correlation with the location of the occurrence of mass movements, or otherwise, the intense precipitation resulting from the passage of convective cells tends to show a random distribution from one event to the next, therefore, without any influence on hydro-geomorphological susceptibility [67]. In the case of the rainy event of 20 February, 2010 in Funchal, from the calculation of the number of hours of rainfall above typical thresholds and the spatial estimation of this statistical information using the ordinary kriging method, it was possible to find that certain areas of the upper sector of Funchal streams, where there was a greater number of landslides, coincides with the persistence of hourly rainfall over $30 \mathrm{~mm}$ for more than $3 \mathrm{~h}$.

In general, the synthesis map obtained (Figure 2d) indicates that intense precipitation tends to occur in the highest areas of the municipality as well as in the range of intermediate altitudes, roughly comprised between 400 and $700 \mathrm{~m}$, affecting the urbanized highlands of Funchal where the rugged terrains contribute to the existence of situations of significant hydro-geomorphological instability.

\subsection{Susceptibility Map}

This simplified GIS-based model of mass movement susceptibility evaluation results from the crossing of spatialized information on a set of factors of instability of the terrain, assuming that some of these factors will have greater influence on the production and transport of solid material in the basins. The susceptibility map to mass movements in Funchal is shown in Figure 7. The results were grouped by the natural break classification method [11], into five susceptibility classes: very low, low, moderate, high, and very high. The class interval is obtained according to the greater or lesser proximity between the susceptibility values. The areas of greatest susceptibility are depicted in red, while the safest terrains are shown in green. From a hydro-geomorphological point of view, the results obtained basically provide a general perception of the areas of greater risk as well as of the safest areas.

The main orange and red spots coincide with the slope of the upper sectors of the basins, marked by the deep incision of the valleys. The susceptibility map obtained tells us that in these sectors, where the slopes are steep, the rain is strong and the type of soil are more permeable, there is a greater propensity for the occurrence of mass movements. The relationships between intense precipitation and soil moisture conditions and land use depend on various circumstances and are determinant in the production of surface runoff. Whenever the events of intense precipitation on natural terrain lead to the rapid saturation of the soils or occur when they are already saturated, the floods thus generated will have greater severity. In these circumstances, the permeability level of a non-urban saturated area and of an urban area may be similar after an event of intense and relatively prolonged precipitation [69].

According to the map of Figure 7, approximately $12.6 \%$ of the municipality area is classified as very high susceptibility and $23 \%$ as high susceptibility, while very low susceptible soils cover about $15.2 \%$; the classes of moderate and low susceptibility represent 26.8 and $22.3 \%$ of the land, respectively. The areas of greatest susceptibility are located mainly along the middle line of the municipality, above $500 \mathrm{~m}$ of altitude, where the mountains are cut by deep, narrow bottomed valleys, that promote a greater interaction between slope processes (landslides and debris flow) and the river dynamics. 
In general, a significant part of the low susceptibility areas is in the western part of the municipality, of equally irregular relief, but at relatively lower altitudes and outside the area of the three main basins of Funchal. It is worth noting that under the general territorial planning options of the revised Municipal Master Plan (approved in March 2018), this zone of urban periphery, with interstitial spaces, was elected for the development of a new urbanity, precisely, because it gathers the appropriate physical conditions for urban occupation.

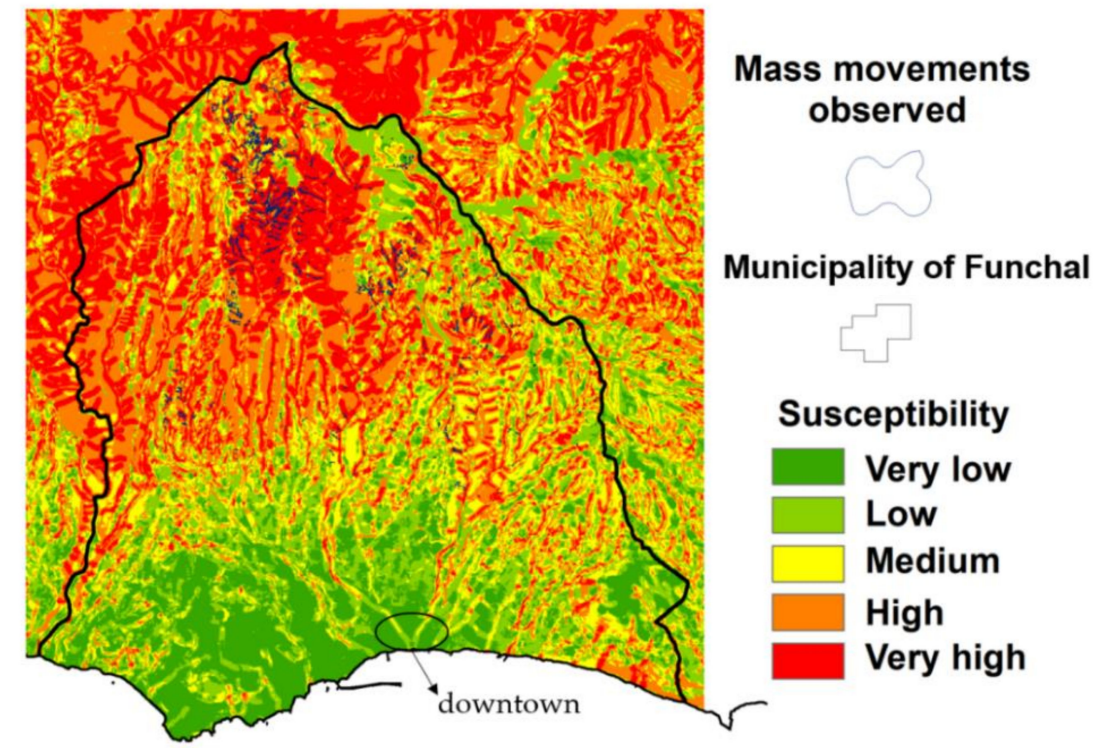

Figure 7. Susceptibility to mass movements in Funchal.

\section{Discussion}

The multicriteria analysis is based on the conjugation of factors of drainage in the watersheds, that are integrated into a spatial model using Geographical Information Systems, to create the final susceptibility map. The goal is to obtain a general spatial framework of the slopes and of the streamlines that are identified through a classification of risk intensity, between the very low level and the very high. In other studies, different predisposing variables have been used, i.e., the altitude, the stream power index and the topographic wetness index [20], which are complementary to those that were considered in this case study. However, these variables were not considered because the aim of the paper was to present a global perception of areas with greater propensity for mass movements, in a way that is easy to explain to policy makers the basic principles of the chosen method. On the other hand, it is easy to update the mass movement susceptibility map through time. However, we recognize that on a more detail scale, the variables mentioned above will allow a more rigorous assessment of spatial risk variation.

The susceptibility model adopted represents a simplified methodological approach to facilitate the quick spatial identification of risk zones, in particular with regard to the complex mix of processes that lead to mass movements formation and subsequent flow trajectories towards and along the valley bottoms, since it requires less basic input data and the time required to perform it is low, comparative to other methods [8]. In practice, it is about adopting a pragmatic method for evaluating susceptibility to mass movements and composite flash floods, supported by the specific knowledge related to aspects of slope movements, debris flow, and flash floods, and the respective assessment procedures of the interactions generated between these types of phenomena. Regional-level susceptibility maps allow for an overview of the risk, from which it is possible to identify the localities where fieldwork must be carried out, for further elaboration of more accurate risk maps [8].

The analysis of spatial concordance with the known historical events allowed to validate the chosen model. However, in cases where there is no clear correlation between the results of the models 
of susceptibility and the information on the spatial incidence of the known events, does not mean that a certain part of the slope or the bottom of the valley is not susceptible to being affected by hydro-geomorphological processes [11], due to the randomness of heavy rain events and circumstances of occurrence of extreme events. It should be noted that, sometimes, the magnitude and spatial incidence of mass movements in the bottom of the valleys is influenced by the accumulation inside the fluvial channel of high concentrations of debris. This kind of punctual fluvial obstruction problem cannot be incorporated into the susceptibility analysis model implemented here.

Among the explanatory variables that were selected in this work, the information regarding the spatial distribution pattern of the intense precipitations is emphasized, for being a few times considered in studies of this nature. Finding the proper method to estimate the spatialization of precipitation data is not an easy task due to its high spatial variability. The choice of the suitable interpolator depends fundamentally on the spatial distribution and density of the pluviometric stations [70], and on the time interval in analysis (annual, monthly, daily, and subdaily precipitation). Regarding the intense precipitations, since by the conventional method of simple linear regression with the altitude, it has been demonstrated that the spatial correlation between these two variables tends to be low [71,72], it was chosen to use the Kriging method, which is indicated in the scientific literature as being more appropriate for short-term precipitations [73] and when the correlation altitude/precipitation is relatively low [74].

\section{Conclusions}

The urban expansion and the increase in the construction density that has been and still is a feature of the development of Funchal, have reinforced the need and the importance of having accurate information resulting from the evaluation of susceptibility to mass movements and flash floods.

The results obtained show that high and very high susceptibility is more significant in the upper sectors of the basins, with its deep cut valleys. It should be underlined that this is not a map related to flood dynamics through the aggregation of stream bed or blocking of a stream course, and in this sense, it does not show the fluvial flat margin areas, where, in a situation of bankfull discharge, the solid material is stopped. However, it must not be forgotten that debris flow and flash floods run further down, along these valleys, to the downtown part of the city, where the three main streamlines run. Conversely, the susceptibility is low in the western part of the municipality. In this way, this susceptibility map to mass movements represents a layer of information on torrential processes, such as landslide and debris flow, which can serve to complement and to improve the quality of existing spatial information on flood zones and risk of flooding, previously elaborated, following only the assumption of rise in streamline water level.

When the process of integration into a single map and harmonization of information about the various hazards existing in a given area is complete, it is imperative to move to the stage of establishing clear and objective standards for the regulation of land use and occupation of the streambeds, of the streambanks and the flood zones, allowing the definition of a space reserved to the streamline, so that it can fully perform its functions.

The river banks are open spaces that must be maintained without any kind of constructions/built interventions, to facilitate the progression of mixed flows, ensuring normal hydrological and hydraulic functioning and ensuring the safety and integrity of people and goods.

Author Contributions: Investigation, S.L., M.F. and A.L. All authors have read and agreed to the published version of the manuscript.

Funding: This research was funded by the Portuguese Science and Technology Foundation (FCT-MCTES) and FCT—Fundação para a Ciência e Tecnologia, I.P. (CEG project number: UID/GEO/00295/2019).

Acknowledgments: This work was supported by the project BeSafeSlide—Landslide early warning soft technology prototype to improve community resilience and adaptation to environmental change (PTDC/GES-AMB/30052/2017).

Conflicts of Interest: The authors declare no conflict of interest. 


\section{References}

1. Gaume, E.; Bain, V.; Bernardara, P.; Newinger, O.; Barbuc, M.; Bateman, A.; Blaskovicova, L.; Bloschl, G.; Borga, M.; Dumitrescu, A.; et al. A compilation of data on European flash floods. J. Hydrol. 2009, 367, 70-78, ISSN 0022-1694. [CrossRef]

2. Tarolli, P.; Borga, M.; Morin, E.; Delrieu, G. Analysis of flash flood regimes in the NorthWestern and South-Eastern Mediterranean regions. Nat. Hazards Earth Syst. Sci. 2012, 12, 1255-1265. [CrossRef]

3. Costa, J.E. Rheologic, geomorphic, and sedimentologic differentiation of water floods, hyperconcentrated flows, and debris flows. In Flood Geomorphology; Baker, V.R., Kochel, R.C., Patton, P.C., Eds.; John Wiley \& Sons, Inc.: Chichester, UK, 1988; pp. 113-122.

4. Scott, K.M. Origins, behavior, and sedimentology of lahars and lahar-runout flows in the Toutle-Cowlitz River System. US Geol. Surv. Prof. Paper 1988, 1447-A, 1-74.

5. Totschnig, R.; Fuchs, S. Mountain torrents: Quantifying vulnerability and assessing uncertainties. Eng. Geol. 2013, 155, 31-44. [CrossRef] [PubMed]

6. Santangelo, N.; Santo, A.; Di Crescenzo, G.; Foscari, G.; Liuzza, V.; Sciarrotta, S.; Scorpio, V. Flood susceptibility assessment in a highly urbanized alluvial fan: The case of Sala Consilina (Southern Italy). Nat. Hazards Earth Syst. Sci. 2011, 11, 2765-2780. [CrossRef]

7. Scorpio, V.; Santangelo, N.; Santo, A. Multiscale map analysis in alluvial fan flood-prone areas. J. Maps 2016, 12, 382-393. [CrossRef]

8. Delrieu, G.; Nicol, J.; Yates, E.; Kirstetter, P.-E.; Creutin, J.-D.; Anquetin, S.; Obled, C.; Saulnier, G.-M.; Ducrocq, V.; Gaume, E.; et al. The catastrophic flash-flood event of 8-9 September 2002 in the Gard region, France. A first case study for the Cévennes-Vivarais Mediterranean hydro-meteorological observatory. J. Hydrometeorol. 2005, 6, 34-52. [CrossRef]

9. Díez Herrero, A.; Laín-Huerta, L.; Llorente, I.M. Mapas de Peligrosidad por Avenidas e Inundaciones: Guía Metodológica Para su Elaboración; Instituto Geológico y Minero de Espanha: Madrid, Spain, 2008.

10. Mathieu, J.; Provence-Alpes-Côte d'Azur; Direction régionale de l'environnement, and France; Direction générale de l'urbanisme, de l'habitat et de la construction. L'approche Hydrogéomorphologique en Milieux Méditerranéens Une Méthode de Détermination des Zones Inondables; Direction Régionale de l'Environment Provence-Alpes: Aix-en-Provence, France, 2007.

11. Feldman, A. Hydrologic Modeling System HEC-HMS-Technical Reference Manual 4.0, U.S. Army Corps of Engineers. 2013. Available online: https://www.hec.usace.army.mil/software/hec-hms/documentation/HECHMS_Users_Manual_4.0.pdf (accessed on 17 December 2019).

12. Ferreira, R.M.L.; Franca, M.J.; Leal, J.G.; Cardoso, A.H. Mathematical modelling of shallow flows: Closure models drawn from grain-scale mechanics of sediment transport and flow hydrodynamics. Can. J. Civ. Eng. 2009, 36, 1605-1621. [CrossRef]

13. Saharia, M.; Kirstetter, P.-E.; Vergara, H.; Gourley, J.J.; Hong, Y.; Giroud, M. Mapping flash flood severity in the United States. J. Hydrometeorol. 2017, 18, 397-411. [CrossRef]

14. Smith, G. Flash flood potential: Determining the hydrologic response of FFMP basins to heavy rain by analyzing their physiographic characteristics. 2003. Available online: http://www.cbrfc.noaa.gov/papers/ffp_ wpap.pdf (accessed on 17 December 2019).

15. Wallingford, H. Flood Risks to People Phase 2, The Flood Risk to People Methodology; Technical Report FD2321/TR1; Environment Agency $\backslash$ Defra R\&D: London, UK, 2005.

16. Horton, P.; Jaboyedoff, M.; Rudaz, B.; Zimmermann, M. Flow-R, a model for susceptibility mapping of debris flows and other gravitational hazards at a regional scale. Nat. Hazard Earth Syst. Sci. 2013, 13, 869-885. [CrossRef]

17. Kourgialas, N.N.; Karatzas, G.P. Flood management and a GIS modelling method to assess flood-hazard areas-A case study. Hydrol. Sci. J. 2011, 56, 212-225. [CrossRef]

18. Santos, P.P.; Reis, E. Assessment of stream flood susceptibility: A cross-analysis between model results and flood losses. Flood Risk Manag. 2017. [CrossRef]

19. Tehrany, M.S.; Pradhan, B.; Jebur, M.N. Flood susceptibility mapping using a novel ensemble weights-of-evidence and support vector machine models in GIS. J. Hydrol. 2014, 512, 332-343. [CrossRef]

20. Marchi, L.; Borga, M.; Preciso, E.; Gaume, E. Characterisation of selected extreme flash floods in Europe and implications for flood risk management. Hydrol. Process. 2010, 23, 2714-2727. [CrossRef] 
21. Mazzorana, B.; Comiti, F.; Scherer, C.; Fuchs, S. Developing consistent scenarios to assess flood hazards in mountain streams. J. Environ. Manag. 2012, 94, 112-124. [CrossRef]

22. Mazzorana, B.; Fuchs, S. Fuzzy formative scenario analysis for woody material transport related risks in mountain torrents. Environ. Modell. Softw. 2010, 25, 1208-1224. [CrossRef]

23. Borga, M.; Stoffel, M.; Marche, L.; Francesco, M.; Jakob, M. Hydrogeomorphic response to extreme rainfall in headwater systems: Flash floods and debris flows. J. Hydrol. 2014, 518, 194-205. [CrossRef]

24. Cristiano, E.; Veldhuis, M.; Giesen, N. Spatial and temporal variability of rainfall and their effects on hydrological response in urban areas-A review. Hydrol. Earth Syst. Sci. 2017, 21, 3859-3878. [CrossRef]

25. Berne, A.; Delrieu, G.; Creutin, J.; Obled, C. Temporal and spatial resolution of rainfall measurements required for urban hydrology. J. Hydrol. 2004, 299, 166-179. [CrossRef]

26. Ochoa-Rodriguez, S.; Wang, L.-P.; Gires, A.; Pina, R.D.; Reinoso-Rondinel, R.; Bruni, G.; Ichiba, A.; Gaitan, S.; Cristiano, E.; van Assel, J.; et al. Impact of Spatial and Temporal Resolution of Rainfall Inputs on Urban Hydrodynamic Modelling Outputs: A MultiCatchment Investigation. J. Hydrol. 2015, 531, 389-407. [CrossRef]

27. Rafieeinasab, A.; Norouzi, A.; Kim, S.; Habibi, H.; Nazari, B.; Seo, D.-J.; Lee, H.; Cosgrove, B.; Cui, Z. Toward high-resolution flash flood prediction in large urban areas-Analysis of sensitivity to spatiotemporal resolution of rainfall input and hydrologic modeling. J. Hydrol. 2015, 531, 370-388. [CrossRef]

28. Yang, L.; Smith, J.A.; Baeck, M.L.; Zhang, Y. Flash flooding in small urban watersheds: Storm event hydrological response. Water Resour. Res. 2016, 52, 4571-4589. [CrossRef]

29. Fragoso, M.; Trigo, R.M.; Pinto, J.G.; Lopes, S.; Lopes, A.; Ulbrich, S.; Magro, C. The 20 February 2010 Madeira flash-floods: Synoptic analysis and extreme rainfall assessment. Nat. Hazards Earth Syst. Sci. 2012, 12, 1-16. [CrossRef]

30. Couto, F.T.; Salgado, R.; Costa, M.J. Analysis of intense rainfall events on Madeira Island during the 2009/2010 winter. Nat. Hazards Earth Syst. Sci. 2012, 12, 2225-2240. [CrossRef]

31. Gorricha, J.; Lobo, V.; Costa, A.C. Spatial characterization of extreme precipitation in Madeira island using geostatistical procedures and a 3D SOM. In Proceedings of the The Fourth International Conference on Advanced Geographic Information Systems, Applications, and Services, GEOProcessing, Valencia, Spain, 30 January-4 February 2012; Rückemann, C.-P., Resch, B., Eds.; IARIA: Wilmington, DE, USA, 2012; pp. 98-104.

32. Dasari, H.P.; Salgado, R. Numerical modelling of heavy rainfall event over Madeira Island in Portugal: Sensitivity to different micro physical processes. Meteorol. Appl. 2013, 22, 113-127. [CrossRef]

33. Levizzani, V.; Laviola, S.; Cattani, E.; Costa, M.J. Extreme precipitation on the Island of Madeira on 20 February 2010 as seen by satellite passive microwave sounders. Eur. J. Remote Sens. 2013, 46, 475-489. [CrossRef]

34. Luna, T.; Rocha, A.; Carvalho, A.C.; Ferreira, J.A.; Sousa, J. Modelling the extreme precipitation event over Madeira Island on 20 February 2010. Nat. Hazards Earth Syst. Sci. 2011, 11, 2437-2452. [CrossRef]

35. Lira, C.; Lousada, M.; Falcão, A.P.; Gonçalves, A.B.; Heleno, S.; Matias, M.; Pereira, M.J.; Pina, P.; Sousa, A.J.; Oliveira, R.; et al. The 20 February 2010 Madeira Island flash-floods: VHR satellite imagery processing in support of landslide inventory and sediment budget assessment. Nat. Hazards Earth Syst. Sci. 2013, 13, 709-719. [CrossRef]

36. Creutin, J.D.; Borga, M.; Gruntfest, E.; Lutoff, C.; Zoccatelli, D.; Ruin, I. A space and time framework for analyzing human anticipation of flash floods. J. Hydrol. 2013, 482, 14-24. [CrossRef]

37. Alfieri, L.; Salamon, P.; Pappenberger, F.; Wetterhall, F.; Thielen, J. Operational early warning systems for water-related hazards in Europe. Environ. Sci. Policy 2012, 21, 35-49. [CrossRef]

38. Collier, C. Flash flood forecasting: What are the limits of predictability? Q. J. R. Meteorol. Soc. 2007, 133, 3-23. [CrossRef]

39. Liechti, K.; Panziera, L.; Germann, U.; Zappa, M. The potential of radar-based ensemble forecasts for flash-flood early warning in the southern Swiss Alps. Hydrol. Earth Syst. Sci. 2013, 17, 3853-3869. [CrossRef]

40. Quintero, F.; Sempere-Torres, D.; Berenguer, M.; Baltas, E. A scenario-incorporating analysis of the propagation of uncertainty to flash flood simulations. J. Hydrol. 2012, 460, 90-102. [CrossRef]

41. Linacre, E. Climate Data and Resources: A Reference and Guide; Routledge: London, UK, 1992.

42. TT-DEWCE WWO. Guidelines on the Definition and Monitoring of Extreme Weather and Climate Events: Draft Version; First Review by TT-Dewce; 2016. 
43. Goovaerts, P. Geostatistics for Natural Resources Evaluation; Oxford University Press: New York, NY, USA, 1997.

44. Goovaerts, P. Geostatistical approaches for incorporating elevation into the spatial interpolation of rainfall. J. Hydrol. 2000, 228, 113-129. [CrossRef]

45. Lopes, S.S. Clima e Ordenamento do Território no Funchal. Ph.D. Thesis, Institute of Geography and Spatial Planning, University of Lisabon, Lisbon, Portugal, 2015.

46. Malczewski, J. GIS-based multicriteria decision analysis: A survey of the literature. Int. J. Geogr. Inf. Sci. 2006, 20, 703-726. [CrossRef]

47. Saini, S.S.; Kaushik, S.P. Risk and vulnerability assessment of flood hazard in part of Ghaggar Basin: A case study of Guhla block, Kaithal, Haryana, India. Int. J. Geomat. Geosci. 2012, 3, 42-52.

48. Reis, E. Análise de bacias hidrográficas, susceptibilidade à ocorrência de cheias e Sistemas de Informaçao Geográfica: Da definição do quadro conceptual até à proposta de um modelo de avaliaçao [Watershed analysis, flood susceptibility and Geographic Information, S.]. In Proceedings of the VIII Congresso da Geografia Portuguesa, Portuguese Association of Geographers, Lisbon, Portugal, 26-29 October 2011; pp. 1-6.

49. Glade, T.; Crozier, M.J. A review of scale dependency in landslide hazard and risk analysis. In Landslide Hazard and Risk; Glade, T., Anderson, M., Crozier, M.J., Eds.; Jonh Wiley \& Sons, Ltd.: Chichester, UK, 2005; pp. 75-138.

50. Popescu, M.E. A suggested method for reporting landslide causes. Bull. Assoc. Int. Géol. Ingénieur 1994, 50, 71-74. [CrossRef]

51. Zêzere, J.L. Relatório do Programa de Perigosidade, Vulnerabilidade e Riscos no Território: Aplicação aos Movimentos de Vertente; Provas de Agregação; Universidade de Lisboa: Lisbon, Portugal, 2010.

52. de Lima, J.L.M.P. (Ed.) Hidrologia Urbana: Conceitos Básicos; Série Cursos Técnicos No 1; Entidade Reguladora dos Serviços de Águas e Resíduos (ERSAR): Lisbon, Portugal, 2010.

53. Hill, C.; Verjee, F.; Barrett, C. Flash Flood Early Warning System Reference Guide; University Corporation for Atmospheric: Boulder, CO, USA, 2010.

54. Picarelli, L.; Oboni, F.; Evans, S.G.; Mostyn, G.; Fell, R. Hazard characterization and quantification. In Landslide Risk Management; Hungr, O., Fell, R., Couture, R., Eberhardt, E., Eds.; Taylor \& Francis: London, UK, 2005; pp. 27-61. ISBN 04-1538-043-X.

55. Hipólito, J.R.; Vaz, A.C. Hidrologia e Recursos Hídricos; IST Press: Lisbon, Portugal, 2011.

56. Pallard, B.; Castellarin, A.; Montanari, A. A look at the links between drainage density and flood statistics. Hydrol. Earth Syst. Sci. 2009, 13, 1019-1029. [CrossRef]

57. Ramos, C. Os Recursos Hídricos. In Geografia de Portugal; Medeiros, C.A., Ed.; O Ambiente Físico, Círculo de Leitores: Lisbon, Portugal, 2005; Volume I, pp. 388-415. ISBN 972-42-3519-X.

58. Leal, M. As Cheias Rápidas em Bacias Hidrográficas da AML Norte: Factores Condicionantes e Desencadeantes; Núcleo de Investigação em Sistemas Litorais e Fluviais, SLIF 8, Centro de Estudos Geográficos, Universidade de Lisboa: Lisbon, Portugal, 2012; ISBN 978-972-636-231-9.

59. McCuen, R. A Guide to Hydrologic Analysis Using SCS Methods; Prentice-Hall, Inc.: Englewood Cliffs, NJ, USA, 1982.

60. Lencastre, A.; Franco, F.M. Lições de Hidrologia; Fundação da Faculdade de Ciências e Tecnologia da Universidade Nova de Lisboa: Lisbon, Portugal, 2006.

61. Brierley, G.J.; Fryirs, K.A. Geomorphology and River Management: Applications of the River Styles Framework; Blackwell Publications: Oxford, UK, 2005.

62. Mishra, S.K.; Singh, V.P. Soil Conservation Service Curve Number (SCS-CN) Methodology. In Water Science and Technology; Springer: Amsterdam, The Netherlands, 2003; Volume 42, ISBN 978-1-4020-1132-0.

63. Zêzere, J.L.; Trigo, R.M.; Fragoso, M.; Oliveira, S.C.; Garcia, R.A.C. Rainfall-triggered landslides in the Lisbon region over 2006 and relationships with North Atlantic Oscillation. Nat. Hazards Earth Syst. Sci. 2008, 8, 483-499. [CrossRef]

64. Van Den Eeckhaut, M.; Reichenbach, F.; Guzzetti, P.; Rossi, M.; Poesen, J. Combined landslide inventory and susceptibility assessment based on different mapping units: An example from the Flemish Ardennes, Belgium. Nat. Hazards Earth Syst. Sci. 2009, 9, 507-521. [CrossRef]

65. Almeida, A.; Oliveira, R.P.; Gonçalves, A.B.; Flor, A.F.; Sousa, A.J.; Coutinho, M.A.; Ferreira, R.L.; Pereira, M.J.; Pereira, M.C.; Lousada, M.S.; et al. Estudo de Avaliação de Risco de Aluviões na Ilha da Madeira; Final Report; Instituto Superior Técnico: Lisbon, Portugal, 2010; p. 1008. (In Portuguese) 
66. Couto, F.T.; Salgado, R.; Costa, M.J.; Prior, V. Precipitation in the Madeira Island over a 10-year period and the meridional water vapour transport during the winter seasons. Int. J. Climatol. 2015, 35, 3748-3759. [CrossRef]

67. Chang, K.T.; Chiang, S.H.; Lei, F. Analysing the relationship between typhoon triggered landslides and critical rainfall conditions. Earth Surface Process. Landf. 2008, 33, 1261-1271. [CrossRef]

68. MacLeod, A. Coupling Meteorological Data With Hydrologic and Slope Stability Models to Constrain Controls on Shallow Landsliding. M.S. Thesis, University of Oregon, Eugene, OR, USA, 2006.

69. Minder, R.J.; Roe, G.H.; Montgomery, D.R. Spatial patterns of rainfall and shallow landslide susceptibility. Water Resour. Res. 2009, 45, 1-11. [CrossRef]

70. Couto, F.T.; Ducrocq, V.; Salgado, R.; Costa, M.J. Numerical simulations of significant orographic precipitation in Madeira island. Atmos. Res. 2016, 169, 102-112. [CrossRef]

71. Smith, K.; Ward, R. Floods: Physical Processes and Human Impacts; John Wiley and Sons: Chichester, UK, 1998.

72. Childs, C. Interpolating surfaces in ArcGIS spatial analyst. ArcUser July Sept. 2004, 3235, 569.

73. Sanchez-Moreno, J.F.; Mannaerts, C.M.; Jetten, V. Influence of topography on rainfall variability in Santiago Island, Cape Verde. Int. J. Climatol. 2013. [CrossRef]

74. Kieffer-Weisse, A.; Bois, P. A comparison of methods for mapping statistical characteristics of heavy rainfall in the French Alps: The use of daily information. Hydrol. Sci. J. 2002, 47, 739-752. [CrossRef]

(C) 2020 by the authors. Licensee MDPI, Basel, Switzerland. This article is an open access article distributed under the terms and conditions of the Creative Commons Attribution (CC BY) license (http://creativecommons.org/licenses/by/4.0/). 